\title{
ERS/EAACI statement on severe exacerbations in asthma in adults: facts, priorities and key research questions
}

\author{
Arnaud Bourdin ${ }^{1}$, Leif Bjermer ${ }^{2}$, Christopher Brightling $^{3}$, Guy G. Brusselle ${ }^{4}$, \\ Pascal Chanez ${ }^{5}$, Kian Fan Chung ${ }^{6}$, Adnan Custovic ${ }^{7}$, Zuzana Diamant ${ }^{8,9}$, \\ Sarah Diver ${ }^{10}$, Ratko Djukanovic ${ }^{11}$, Dominique Hamerlijnck (10 ${ }^{12}$, Ildikó Horváth ${ }^{13}$, \\ Sebastian L. Johnston ${ }^{14}$, Frank Kanniess ${ }^{15}$, Nikos Papadopoulos ${ }^{16,17}$, \\ Alberto Papi $\mathbb{1}^{18}$, Richard J. Russell ${ }^{19}$, Dermot Ryan (10)20,21, \\ Konstantinos Samitas ${ }^{22}$, Thomy Tonia ${ }^{23}$, Eleftherios Zervas $\mathbb{1}^{24}$ and Mina Gaga (10 ${ }^{24}$
}

\begin{abstract}
Affiliations: ${ }^{1}$ Université de Montpellier, CHU Montpellier, PhyMedExp, INSERM, CNRS, Montpellier, France. ${ }^{2}$ Dept of Respiratory Medicine and Allergy, Lung and Allergy research Unit, Lund, Sweden. ${ }^{3}$ Dept of Infection, Immunity and Inflammation, Institute for Lung Health, NIHR BRC Respiratory Medicine, University of Leicester, Leicester, UK. "'Dept of Respiratory Diseases, Ghent University Hospital, Ghent, Belgium. ${ }^{5}$ University of Marseille, Marseille, France. ${ }^{6}$ National Heart and Lung Institute, Imperial College, London, UK. ${ }^{7}$ Dept of Paediatrics, Imperial College London, London, UK. ${ }^{8}$ Dept of Respiratory Medicine and Allergology, Skane University Hospital, Lund, Sweden. ${ }^{9}$ Respiratory and Allergy Research, QPS Netherlands, The Netherlands. ${ }^{10}$ Dept of Respiratory Sciences, College of Life Sciences, Respiratory Biomedical Research Unit, Glenfield Hospital, Leicester, UK. ${ }^{11}$ University Hospital Southampton NHS Foundation Trust, Southampton, UK. ${ }^{12}$ Amsterdam, The Netherlands. ${ }^{13}$ National Koranyi Institute for Pulmonology, and Dept of Public Health, Semmelweis University, Budapest, Hungary. ${ }^{14}$ Dept of Respiratory Medicine, Imperial College London, London, UK. ${ }^{15}$ Reinfeld, Germany. ${ }^{16}$ Division of Infection, Immunity and Respiratory Medicine, University of Manchester, Manchester, UK. ${ }^{17}$ Allergy Dept, 2nd Pediatric Clinic, University of Athens, Athens, Greece. ${ }^{18}$ Respiratory Medicine, University of Ferrara, Ferrara, Italy. ${ }^{19}$ Institute for Lung Health, NIHR Leicester Biomedical Research Centre, Dept of Infection, Immunity and Inflammation, University of Leicester, Leicester, UK. ${ }^{20}$ Allergy and Respiratory Research Group, Centre for Population Health Sciences, University of Edinburgh, Edinburgh, UK. ${ }^{21}$ Woodbrook Medical Centre, Loughborough, UK. ${ }^{22} 7$ th Resp. Med. Dept and Asthma Centre, Athens Chest Hospital, Athens, Greece. ${ }^{23}$ Institute of Social and Preventive Medicine, University of Bern, Bern, Switzerland. ${ }^{24} 7$ th Respiratory Medicine Dept, Athens Chest Hospital, Athens, Greece.
\end{abstract}

Correspondence: M. Gaga, Athens Chest Hospital Sotiria, 7th Respiratory Medicine Dept, 152 Mesogion Ave, Athens, 15452, Greece. Email: minagagadyahoo.com

\section{@ERSpublications}

ERS/EAACI statement on severe exacerbations in asthma in adults http://bit.ly/2Hl8sqf

Cite this article as: Bourdin A, Bjermer L, Brightling C, et al. ERS/EAACI statement on severe exacerbations in asthma in adults: facts, priorities and key research questions. Eur Respir J 2019; 54: 1900900 [https://doi.org/10.1183/13993003.00900-2019].

ABSTRACT Despite the use of effective medications to control asthma, severe exacerbations in asthma are still a major health risk and require urgent action on the part of the patient and physician to prevent serious outcomes such as hospitalisation or death. Moreover, severe exacerbations are associated with substantial healthcare costs and psychological burden, including anxiety and fear for patients and their families. The European Academy of Allergy and Clinical Immunology (EAACI) and the European Respiratory Society (ERS) set up a task force to search for a clear definition of severe exacerbations, and to also define research questions and priorities. The statement includes comments from patients who were members of the task force.

This document was endorsed by the ERS Executive Committee on 14 August, 2019, and by the European Academy of Allergy and Clinical Immunology.

This article has supplementary material available from erj.ersjournals.com

Received: 5 May 2019 | Accepted after revision: 17 July 2019

Copyright $\odot$ ERS 2019 


\section{Introduction}

Asthma is one of the most common chronic diseases and its worldwide prevalence has risen around three-fold in recent decades [1]. With the recognition of the inflammatory nature of the disease and the introduction of inhaled corticosteroids, asthma control and the quality of life of asthma patients have substantially improved and many deaths have been prevented. Nevertheless, patients still face exacerbations of varying severity, ranging from increased symptoms to life-threatening episodes. Any asthmatic patient may suffer a severe exacerbation and even die from one; in fact, most exacerbations present in mild asthmatics, who are the majority of asthma sufferers [2,3]. The causes leading to exacerbations may be exposure to a triggering agent, lack of adherence to treatment or the inherent severity and hyperresponsiveness of the disease, and may be affected by comorbidities. Severe exacerbations of asthma likely carry most of the burden of the disease through their immediate and delayed associated risks. Severe exacerbations expose patients to immediate and delayed side-effects of high doses of bronchodilators and systemic corticosteroids, and quite often to antibiotics. Absenteeism, presenteeism, care-associated risks if admitted (nosocomial infection for example), anxiety and many other issues insufficiently describe all components of the burden of severe exacerbations. Epidemiological data remain heterogenous as very different definitions are used in cohorts and in clinical trials. For example, in TENOR II, 25.8\% of the population reported a severe exacerbation [4]. In the MENSA study, among enrolled patients who reported $3.5 \pm 2.2$ exacerbations before entering the study, $17-21 \%$ were admitted. During the trial, the mean rate of clinically significant exacerbation and exacerbation requiring admission fell to 1.74 and 0.10 respectively [5]. Unfortunately, asthma deaths still exist. Their rates are low and most of them are seen as preventable $[6,7]$ in westernised countries. This also implies that some are not preventable, suggesting a place for new drugs to treat refractory episodes of near fatal asthma.

Accordingly, both the European Respiratory Society (ERS) and the European Academy of Allergy and Clinical Immunology (EAACI) elicited a task force in 2016 that aimed to review the most relevant research evidence and the current practice on definition, clinical identification of severe exacerbations, triggers and risk factors, management, and prevention. Subsequently, this document does not contain recommendations for clinical practice but offers recommendations for future research.

\section{Methodology}

After the initial meetings, the task force members decided to address four main research questions related to serious exacerbations. 1) What are the available definitions for severe exacerbations in asthmatics and what would be an accurate definition? 2) Which are the trigger factors related to the initiation and severity of exacerbations? 3) What is the best way to manage severe exacerbations? 4) What is the best strategy to prevent them? Specific keywords and MeSH terms were identified based on several key references provided by the task force members, and the corresponding literature search was initiated for all sections using the MEDLINE and CENTRAL (Cochrane Library) Databases. Search results were extracted in .txt file formats and imported in a specially designed reference management software (Reference Manager Version 12) in order to screen for duplicates. Further processing of the search results was made in a stepwise approach (as shown in the supplementary material flow charts) based on the title, the abstract, and finally after reading the whole text, filtering for date (2000 and onwards), age (adults only), language (only English), and type (included: randomised and observational studies, and systematic reviews/meta-analyses; excluded: case reports and letters to the editor). All articles remaining after final processing for each section were sent back to the corresponding task force members for final evaluation (corresponding flow charts are available in the supplementary material). From this sorting of the relevant literature, leaders of the four sections drafted a first version and each statement was kept or removed if any concern was expressed and no consensus could be found. During the subsequent dedicated meetings, research needs were identified, and tables and figures were reviewed.

\section{Definition of severe exacerbations of asthma}

Asthma severity and control have more or less been defined and graded over the years so that the definitions are equally understood by all stakeholders [3, 8-10]. This is not yet the case for asthma exacerbations, where exacerbations are defined as episodes characterised by more or less rapid increase in symptoms, sufficient to require a change in treatment $[3,11]$. Severe exacerbations are usually defined based on use of systemic, usually oral, corticosteroids (OCS), emergency care visits and/or hospitalisations [1], while in some clinical studies reductions in lung function (peak expiratory flow (PEF) or forced expiratory volume in $1 \mathrm{~s}$ of more than 20 or $30 \%$ have also been included in the definition (table 1 ). It must be noted that patient perception and easy access to rescue corticosteroids and emergency care facilities may confound the definition and so may the retrospective collection of data. The ERS/American Thoracic Society (ATS) statement on exacerbations released in 2009 [12] defines severe exacerbations as 


\begin{tabular}{|c|c|c|}
\hline Section & Section title & Participants \\
\hline 1 & Definitions & M. Gaga (leader) and K. Samitas \\
\hline 2 & Triggers and risk factors & A. Bourdin (leader) \\
\hline $2 A$ & Assessment of risk: what is cause and what is effect? & A. Bourdin \\
\hline $2 B$ & $\begin{array}{l}\text { Modifiable versus non-modifiable factors and } \\
\text { mathematical models }\end{array}$ & K.F. Chung \\
\hline $2 \mathrm{C}$ & Risk factors and epidemiology, pheno/geno/endotypes & I. Horváth \\
\hline $2 D$ & $\begin{array}{l}\text { Typology: gender and psychosocial factors, perception, } \\
\text { compliance/adherence }\end{array}$ & L. Bjermer and F. Kanniess \\
\hline $2 E$ & Virus/allergens & $\begin{array}{l}\text { Z. Diamant, S.L. Johnston and } \\
\text { R. Djukanovic }\end{array}$ \\
\hline $2 F$ & $\begin{array}{l}\text { Environmental factors: indoor/outdoor air pollution and } \\
\text { occupational factors }\end{array}$ & G.G. Brusselle and A. Papi \\
\hline $2 G$ & Drugs and irritants/excessive use of $\beta_{2}$-agonists & P. Chanez and N. Papadopoulos \\
\hline 3 & Acute management & E. Zervas (leader) \\
\hline 4 & Prevention & $\begin{array}{l}\text { C. Brightling (leader), D. Ryan, } \\
\text { R.J. Russell and S. Diver }\end{array}$ \\
\hline 5 & ELF patient perspective & $\begin{array}{l}\text { D. Hamerlijnck and the ELF Patient } \\
\text { Advisory Group }\end{array}$ \\
\hline \multicolumn{2}{|c|}{ ERS senior methodologist } & T. Tonia \\
\hline \multicolumn{2}{|c|}{ Literature search } & K. Samitas \\
\hline
\end{tabular}

events that require urgent action on the part of the patient and physician to prevent a serious outcome, i.e. hospitalisation or death. However, there is subjectivity in the perception of severity and moreover, many studies have shown that the risk of severe exacerbation is associated with a multitude of factors. These factors include 1) the level of asthma control, 2) asthma severity based on ERS/ATS definition [3], 3) lung function, 4) the presence of comorbidities, 5) the psychosocial status (to assess the ability to seek help in case of clinical worsening), 6) previous history of near fatal attacks and 7) response to treatment. Such factors seem important in guiding treatment decisions and, importantly, decisions regarding hospitalisations. Moreover, prediction models assessing future risk of exacerbations in adult asthma patients have been proposed, such as the one published by MILLER et al. [13], based on the TENOR cohort. However, the applicability of such models has not been examined in large studies and needs to be assessed prospectively. Composite scores have been developed for use in other acute respiratory conditions, for example the CURB-65 (confusion, blood urea nitrogen greater than $7 \mathrm{mmol} \cdot \mathrm{L}^{-1}$, respiratory rate $\geqslant 30$ breaths $\mathrm{min}^{-1}$, blood pressure $<90 \mathrm{mmHg}$ (systolic) or $\leqslant 60 \mathrm{mmHg}$ (diastolic), age $\geqslant 65$ years) or Pneumonia Severity Index score for pneumonia or GENEVA score for pulmonary embolism, and they greatly help clinicians in treatment decisions and are important for the safety of the patients. All task force members in their practice consider severe exacerbations of asthma as a significant worsening of the disease that require OCS treatment for at least 5 days. In the ERS/ATS task force report of 2009, a 3-day course of OCS was the recommended definition for clinical trials. This small difference was supported by all task force members as it may differentiate from patients with episodes of loss of control requiring short courses (e.g. 1-2 days) of OCS and from temporary increase of maintenance treatment to improve the control of their disease. These patients may have an accumulated use of OCS over time equivalent to someone with repeated exacerbations but will not be reported as such. Whether 3 or 5 days of OCS is more accurate for discriminating a mild from a severe exacerbation will probably not be addressable in terms of evidence. 1) Herein we report an expert-based opinion that definitely does not intend to change the definition used in trials in order to keep them comparable; and 2) as the harmfulness of cumulative doses of corticosteroids is obvious above $0.5 \mathrm{~g}$ per year [14], a 5-day-based definition would make better fit this OCS-associated risk with the threshold of two exacerbations. Although variable among countries and systems, emergency visit or hospitalisation, the task force members base hospitalisation or initiation of treatment with OCS on the Global Initiative for Asthma (GINA) or British Thoracic Society recommendations to improve standardisation. It seems that it would be important to develop, test and use a composite score that takes into consideration the patient's previous health status, the presence of comorbidities, history of severe or near fatal exacerbations, adherence to treatment, psychosocial status, level of control and, of course, response to treatment (the latter is already factored into asthma exacerbation management guidelines), rather than just clinical severity at presentation and PEF or spirometry values. 
TABLE 1 Examples of definitions of severe exacerbation in asthma patients used in the literature

\begin{tabular}{lll} 
Author [ref] & Definition of severe exacerbation & Comment \\
\hline GINA 2019 [1] & $\begin{array}{l}\text { Exacerbations of asthma are episodes characterised by a } \\
\text { progressive increase in symptoms of shortness of } \\
\text { breath, cough, wheezing or chest tightness and } \\
\text { progressive decrease in lung function, i.e. they }\end{array}$ & $\begin{array}{c}\text { GINA proposes an accurate definition of exacerbations } \\
\text { of asthma. Regarding severe exacerbations, GINA } \\
\text { does not define exact criteria by which to distinguish } \\
\text { severity levels. }\end{array}$
\end{tabular}

REDdel et al. [12]

(ERS/ATS 2009)

\section{Custovic et al. [9] \\ (EAACI 2013)}

\section{0'BYRne et al. [15] 2009}

\section{GREen et al. [16], \\ Pauwels et al. [17] \\ [FACET study]}

\section{JAYARAM et al. [18] 2006}

Demoly et al. [19] 2004

\section{FuHLBRIGGe et al. [20] 2013 (NIH workshop)}

CASTRo et al. 2010 [21]

MURPHY et al. 2010 [22] represent a change from the patient's usual status that is sufficient to require a change in treatment. Definition based on symptoms ("talks in words, sits hunched forward, agitated"), clinical findings (respiratory rate $>30$ per min, heart rate $>120$ per min, oxygen saturation $<90 \%$, use of accessory muscles) and lung function (PEF $<50 \%$ pred).

Severe asthma exacerbations are defined as events that require urgent action on the part of the patient and physician to prevent a serious outcome, such as hospitalisation or death from asthma. The definition should include at least one of the following:

1) Use of systemic corticosteroids or an increase from a stable maintenance dose, for at least 3 days.

2) A hospitalisation or emergency department visit because of asthma, requiring systemic corticosteroids. No specific definition provided.

Defined as events requiring hospitalisation or emergency treatment due to worsening of asthma, or death due to asthma.

Emergency treatment was defined as treatment of acute airway obstruction with systemic corticosteroids and nebulised or parenteral bronchodilators given at a healthcare institution.

Decrease in morning PEF $>30 \%$ on two or more consecutive days, or deterioration in symptoms needing OCS.

Course of OCS as determined by study investigator.

Hospitalisation was unanimously recognised as the first criterion for severe exacerbations. A decrease in peak expiratory flow of more than $30 \%$ below the baseline value on two consecutive days and an episode requiring systemic corticosteroids were the next criteria.

This survey emphasises the complexity of the notions of asthma control and exacerbation.

An exacerbation is a worsening of asthma requiring the use of systemic corticosteroids lor for patients on a stable maintenance dose, an increase in the use of systemic corticosteroids) to prevent a serious outcome (the subcommittee does not endorse severity stratification in the core outcome definition).

Those requiring systemic corticosteroids or doubling of ICS dose.

Defined as episodes requiring medical intervention (hospital admission, emergency department presentation, unscheduled doctor visit or the use of OCS).
Strength: This is the most commonly used definition. Weakness: it relies on patient and doctor subjective assessment, there are no hard criteria for deterioration.

Strength: The task force stresses the need for a consensus definition of asthma exacerbation that could usefully guide treatment.

Weakness: It is not really a definition.

Strengths and weaknesses same as those of REDDEL et al. [12] (ERS/ATS 2009).

Strengths: Adds an objective limit in addition to the need for OCS or the vague "deterioration".

Weakness: $30 \%$ decrease is not universally severe, no reference to length of time.

Weakness: No objective criteria given ("determined by study investigator").

Strengths: This survey emphasises the complexity of the notions of asthma control and exacerbation and reflects real life practice. Uses an objective measure and length of time.

Weakness: No hard criteria.

Strengths and weaknesses same as RedDEL et al. [12]. Addition: increase in use of systemic steroid dose in patients already on steroids.

Weakness: No criteria given for "requiring"; "doubling of ICS dose".

Strengths and weaknesses same as REDDEL et al. [12].

GINA: Global Initiative for Asthma; PEF: peak expiratory flow; ERS: European Respiratory Society; ATS: American Thoracic Society; OCS: oral corticosteroids; ICS: inhaled corticosteroids. 


\section{Triggers and risk factors}

Assessment of risk: what is cause and what is effect?

The prevention of exacerbations is probably the most important aim for patients with asthma and healthcare professionals. In order to achieve this aim, it is important to plan the re-assessment of asthma patients and treatment adjustments because of the immediate risks (i.e. acute respiratory failure, death) and future risks (recurrence of exacerbations, decline in lung function, and side-effects of treatments) [1]. Routine management strategies assess asthma control based on clinical symptoms, history of exacerbations and pulmonary function testing. In addition, in experienced centres, strategies guided by airway hyperresponsiveness or sputum eosinophilia may provide benefit for preventing future exacerbations [16, 23]. In contrast, the use of fractional exhaled nitric oxide $\left(F_{\mathrm{ENO}}\right)$ as a surrogate marker in asthma management is still inconclusive [24-26] except during pregnancy [27]. A recent meta-analysis found more supportive results deserving further evaluations [28].

Since a previous exacerbation has been shown to be an important risk factor for future exacerbations (even though this concept has been challenged) [29], the "frequent exacerbator" likely represents an important clinical phenotype; and asthma treatment should aim to modify what might look like an irreversible cycle [30]. For this purpose, multiple initiatives have investigated and weighed the importance of individual traits in predicting recurrent exacerbations. Many other characteristics and conditions have also been reported, such as amount of asthma medication, comorbidities including obesity, occupational stress [31], sensitisation, indoor and outdoor pollution, small airway dysfunction [32], loss of lung elastic recoil [33], and psychological factors [29, 34-44]. Retrospective studies have shown that repeated assessment of composite scores of control, such as the Asthma Control Test or Asthma Control Questionnaire, and other tools, such as eHealth and mHealth [45], may predict severe exacerbations [46]. However, whether self-monitoring of asthma control score questionnaires at home can be useful to predict (and consequently, help to prevent) exacerbations in a real-life setting needs to be further investigated [47-49]. An index of fluctuation of PEF measurements at home was able to predict exacerbations [50]. Lastly, although a hospital admission provides proof of a severe exacerbation (see definition), the decision to hospitalise a patient with asthma also depends on the clinical course during management at the emergency department $[2,51,52]$, and on additional factors, such as age, inflammatory phenotype, presence of comorbidities $[53,54]$ and familial and social conditions $[2,51,52]$.

\section{Modifiable versus non-modifiable factors and mathematical models}

Until recently, modifiable risk factors for exacerbations were mostly seen as behavioural issues or environmental triggers [55-58]. This included patients' beliefs (or parents' beliefs in the case of children) and expectations, poor inhalation technique and/or treatment adherence, (active or passive) smoking and allergen exposure (such as in-house pets, for example). More recently, the key role of viruses has been acknowledged, and viral triggers are now perceived as potentially modifiable factors. However, no therapeutic strategies have yet been able to successfully interfere with rhinovirus carriage and bouts of infections in children and adults; this is an important area of ongoing research. Accordingly, viral infection and impaired host responses to rhinovirus can be modelled to predict the potential of new antiviral drugs [53, 59-61]. The synergistic action of allergen exposure (e.g. seasonal pollens, house dust mite) and viruses may indicate a place for combining strategies targeting each factor alone or in association $[38,55,62]$.

High blood eosinophil count, reflecting type 2 (T2) inflammation, is well-recognised as a significant risk factor for asthma exacerbations [63], with a consistent dose-ranging effect reproduced in different large-scale studies $[64,65]$. The relative weight of elevated blood eosinophilia with any other predictor of future exacerbation is largely unknown, but is influenced by the level of asthma control, asthma severity, asthma phenotype (e.g. age at onset of asthma), lung function and history of exacerbations. Validated biomarkers reflecting non-T2 asthma phenotype(s) remain an urgent unmet need [66]. The recognition of T2-related traits makes a patient with uncontrolled severe asthma eligible for biological therapies targeting key T2 disease-drivers, such as eosinophils, interleukin (IL)-4, IL-13 and/or IgE [67]. Elevated blood eosinophil count is associated with an increased exacerbation risk and to date this is the most relevant phenotyping marker. The reduction in exacerbation rates provided by anti-IgE-, -TSLP (thymic stromal lymphopoietin), -IL-5 and -IL-4/IL-13 antibody therapy supports the concept that T2-associated asthma is associated with an increased risk of exacerbations [68, 69], even though it is not the only one.

Asthma patients may follow many different trajectories [56]. These trajectories can be described under three main categories and sustain the concept of asthma severity (persistently severe, intermittently severe, never severe). Presently, exacerbations represent one of the key outcomes in asthma with the greatest asthma-related risks as defined by GINA [1] and hence, the development of innovative drugs and effective treatment modalities remains a priority. Exacerbations are episodes of acute respiratory distress; a situation 


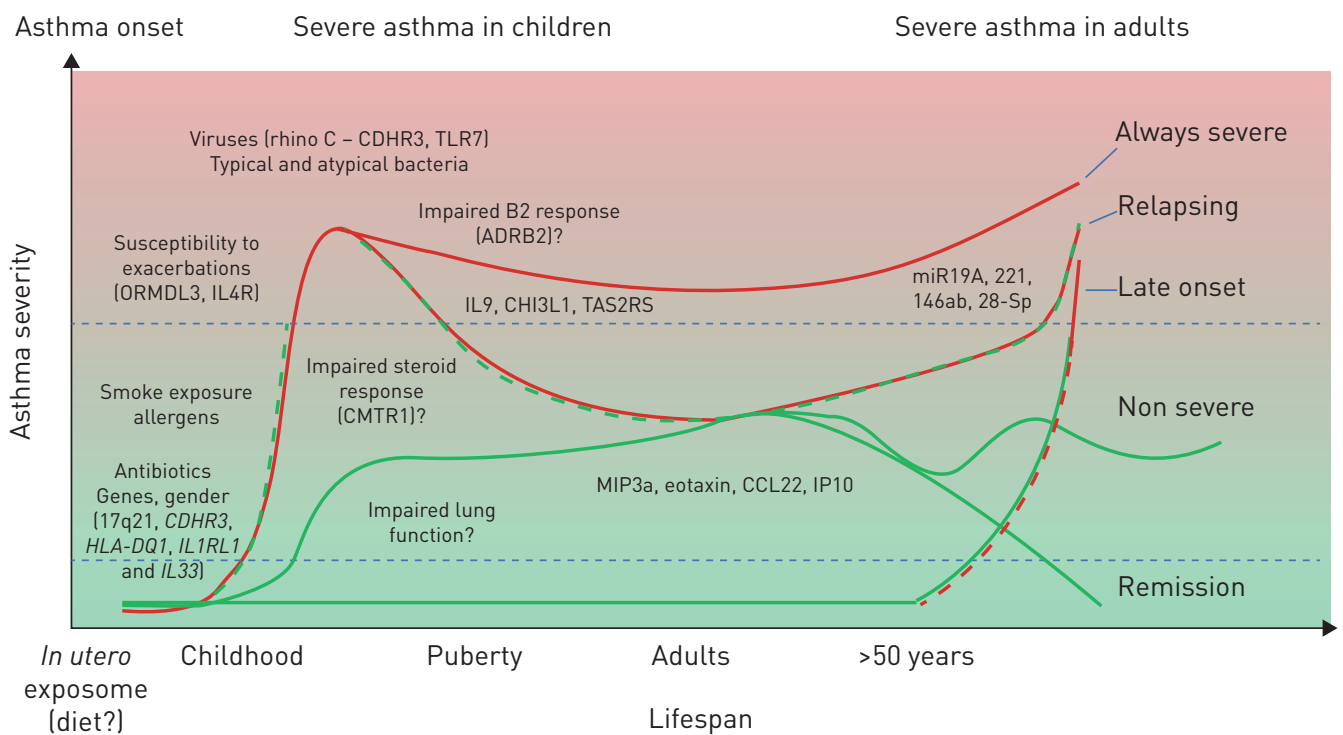

FIGURE 1 Potential severe asthma trajectories and the importance of risk factors and genetic variants (such as single nucleotide polymorphisms). This figure presents a summary of the literature and is not intended to be exhaustive.

that causes major stress for the patient themselves, their relatives and even for the healthcare providers. They represent an important economic burden both in terms of healthcare use and professional absenteeism. They are also associated with long-term risks (relapses, side-effects of treatments dominated by systemic steroids, lung function decline) $[1,9,70]$. Some single nucleotide polymorphisms and other gene modifiers summarised in figure 1 could be associated with such long-term risks [62, 71-82]. It would appear worthwhile exploring the epigenetic modifications in well-characterised asthma populations, particularly in late onset disease.

\section{Risk factors and epidemiology, pheno/geno/endotypes}

Since severity of asthma is presently defined by treatment requirement, which partly relies on previous exacerbation rates [3], the frequency of exacerbations is associated with severity. However, exacerbations are not restricted to patients with the severe form of asthma.

Near-fatal asthma episodes can occur in patients even with so-called "mild asthma", implying that "mild asthma" (GINA step 1 and 2) does not necessarily mean "low risk asthma". Most of the time, these patients are not receiving any anti-inflammatory treatment at the time of the event and their asthma can be well-controlled when it is correctly managed and treated [2, 35]. Near-fatal episodes represent a minority of exacerbations seen in the emergency department [2]. Interestingly, a hyperbolic curve relating inhaled corticosteroid (ICS) prescription refilling and asthma mortality is highly suggestive of a strong death-preventing effect of ICS use [83]. Actually, asthma deaths due to exacerbations have decreased over time in westernised countries. However, their incidence was still estimated to be more than 900 in the UK in the latest National Review of Asthma Deaths, and at least half of these dramatic cases were considered preventable $[6,84]$.

Risk factors and clinical characteristics could be identified and robustly confirmed in different countries. These criteria should be known to all healthcare providers involved in the management of asthma and are shown in table 2.

Better characterisation of disease mechanisms is required in those patients with an incomplete response to ICS (across GINA steps) [70]. Defining clinical phenotypes and mechanistic endotypes is a useful concept that has been developed to better manage these patients [85]. In the SARP-3 cohorts, five factors were positively associated with exacerbation frequency: chronic sinusitis, gastro-oesophageal reflux, blood eosinophils, body mass index and bronchodilator responsiveness. Clusters in primary care identified early onset and obesity as risk factors for exacerbations. A cluster of obese female asthma patients with recurrent exacerbations has been described in both the SARP and UBIOPRED cohorts [86, 87]. Furthermore, a large-scale study on children confirmed that obesity is linked with a shorter period of time between exacerbations [88]. Symptoms such as cough and wheeze are correlated with uncontrolled asthma, but are poorly associated with exacerbations [89]. Interestingly, new inflammatory patterns of 
TABLE 2 Risk factors for various outcomes in asthma exacerbations

\begin{tabular}{|c|c|c|c|}
\hline Risk factor for & Likely & Possible & Ref \\
\hline Dying & $\begin{array}{l}\text { - } \beta_{2} \text {-agonist overuse } \\
\text { - No ICS treatment } \\
\text { - Age } \\
\text { - Virus infection } \\
\text { - Gender } \\
\text { - Drug and venom allergy } \\
\text { - Allergen exposure (including } \\
\text { thunderstorm asthmal }\end{array}$ & $\begin{array}{l}\text { - Intubation outside ICU } \\
\text { - High number of ED visit } \\
\text { - Sports } \\
\text { - Alternaria and penicillium spores } \\
\text { - Nitrogen dioxide, ozone } \\
\text { - Severe asthma }\end{array}$ & {$[35,93-97]$} \\
\hline ICU admission; near fatal asthma & $\begin{array}{l}\text { - No ICS treatment } \\
\text { - Severe asthma } \\
\text { - Virus infection } \\
\text { - Loss of elastic recoil } \\
\text { - Permanent airflow limitation } \\
\text { - Hyperinflation } \\
\text { - Menstruation } \\
\text { - Steroid dependence } \\
\text { - History of intubation } \\
\text { - Delayed systemic corticosteroid use }\end{array}$ & - Heroin, cocaine & {$[33,39,41,98,99]$} \\
\hline Severe exacerbation; ED admission & $\begin{array}{l}\text { - No ICS treatment } \\
\text { - Comorbidities } \\
\text { - Psychological issues } \\
\text { - Age } \\
\text { - Absence of ICS } \\
\text { - Virus infection }\end{array}$ & & \\
\hline $\begin{array}{l}\text { Frequent severe exacerbations } \\
(\geqslant 2-3 \text { OCS bursts per year })\end{array}$ & $\begin{array}{l}\text { - No ICS treatment } \\
\text { - Virus infection } \\
\text { - High blood eosinophil count } \\
\text { - Smoking } \\
\text { - Genetic } \\
\text { - Atopy } \\
\text { - BMI } \\
\text { - BD responsiveness } \\
\text { - Chronic sinusitis }\end{array}$ & $\begin{array}{l}\text { - Low socioeconomic status } \\
\text { - GORD } \\
\text { - Aspirin sensitive } \\
\text { - Climate: thunderstorms during } \\
\text { pollen season }\end{array}$ & {$[54,100,101]$} \\
\hline
\end{tabular}

BD: bronchodilator; BMI: body mass index; ED: emergency department; ICS: inhaled corticosteroids; ICU: intensive care unit; GORD: gastro-oesophageal reflux disease; OCS: oral corticosteroids.

exacerbations are currently described with the integration of the microbiome and T1-related cytokines [90]. A gene signature derived from sputum gene transcriptomics containing Charcot-Leyden crystal galectin (CLC); carboxypeptidase 3 (CPA3); deoxyribonuclease 1-like 3 (DNASE1L3); alkaline phosphatase, liver/bone/kidney (ALPL); CXCR2; and IL1ß (a mixture of eosinophil and mast cell product with neutrophil-associated cytokines) can predict future exacerbation phenotypes of asthma, with the greatest biomarker performance compared to $F_{\mathrm{ENO}}$ values and sputum eosinophil counts in identifying those who would experience frequent severe exacerbations [91].

It should be kept in mind that very high blood eosinophil counts (e.g. more than a thousand per $\mathrm{mm}^{3}$ ) are sometimes associated with other conditions such as eosinophilic granulomatous with polyangiitis or allergic bronchopulmonary aspergillosis, which overlap with severe asthma. These specific conditions are prone to very frequent exacerbations. They are sometimes difficult to discriminate from severe asthma when all the diagnostic criteria are not fulfilled [92].

Typology: gender and psychosocial factors, perception, compliance/adherence

Poor treatment adherence is a major trigger for loss of control at the population level, and this is a common finding also for onset of exacerbations [102]. Although ICS treatment is able to decrease the exacerbation rate at all dose ranges [103], it seems that an adherence of at least $75 \%$ of the prescribed dose (hazard ratio $0.61,95 \%$ CI $0.41-0.90$ ) is required to achieve this goal [103]. Of note, $24 \%$ of exacerbations can be attributed to poor adherence, which is often unintentional due to poor inhalation technique. Moreover, running out of inhaler was frequently reported in asthma patients attending the emergency department [104]. The use of multiple devices, especially when different principles are mixed, such as dry 
powder inhalers and metered dose inhalers (MDIs), is also a risk [105]. Non-consented switching of inhalers has also been shown to be a significant risk factor for exacerbation; these apparent cost-sparing measures in the short-term are thus subsequently countered by increased healthcare utilisation [106]. Alexithymia [107], specific personality traits [108], and poor perception of symptoms may lead to a delayed request for help [95-100]. Female gender [109, 110], ethnicity $[111,112]$ and patient beliefs [113] could also be identified as risk factors for exacerbation. The prevalence of psychological dysfunction, including anxiety and depression, is increased in patients with asthma and has been shown to be related to severity of disease [114]. Anxiety and depression are also strong predictors for poor asthma control [115].

Poor adherence is well-documented for ICS, but new injectable biological therapies also appear susceptible to this, particularly when self-administered [116]. On the other hand, self-administration is likely to improve access to treatment and to reduce the burden of the disease [117].

Several drawbacks could be raised against therapeutic educational programmes, but at present many simple and efficient solutions extensively reviewed elsewhere can work [70, 102]. The benefits of written or web-based action plans are worthy of investigation [118]. Furthermore, e-Health solutions such as electronic reminder messages and, more recently, connected (to a computer or a smartphone) inhaler devices can be implemented and have been shown to be effective $[119,120]$, but as they are usually only geared towards the use of one single inhaler per patient and no other medication it is likely of limited value for patients requiring multiple medications. However, these interventions should be prospectively evaluated for their ability to decrease exacerbation rates over time and whether they are really easing patients' lives. Stronger partnerships between patients and healthcare professionals are likely to improve adherence and new self-adherence programmes should be developed and tested for their effect on preventing (severe) exacerbations.

Although there is no perfect tool for associating a severe asthma exacerbation with poor adherence, a minimal adherence checklist is proposed in GINA and the task force decided to echo it presently (table 3 ). Dose-counter displaying devices are preferred options according to a European Lung Foundation (ELF) open discussion organised for the present task force.

\section{Virus/allergens}

A synergy exists between respiratory viral infections and allergen exposure inducing asthma and causing exacerbations in susceptible, sensitised asthmatics $[38,55,62]$. Additionally, interaction between viral lower respiratory tract infections (LRTIs) and atopic sensitisation has been recognised as a major risk factor contributing to asthma development and exacerbations [62, 121]. Birth cohort studies provide strong evidence for a synergistic effect of viral LRTIs and atopic sensitisation on risk of asthma inception, particularly in predisposed children $[122,123]$. Several studies in both sensitised children [55, 124] and adults $[16,38]$ found a strong association between the levels of specific IgE to inhaled allergens and viral LRTIs in increasing the risk of severe asthma exacerbations requiring hospital admission.

The synergy between allergen sensitisation and viral LRTIs has been indirectly confirmed in a study in asthmatic children, showing that pretreatment with omalizumab decreases asthma exacerbations in the fall/ autumn, which are likely (rhino-) virus-induced [125]. Recent evidence demonstrates that omalizumab restores deficient anti-viral immunity in children with asthma, and that exacerbation reduction with omalizumab was greatest in those with greatest restoration of anti-viral immunity [125]. Rhinoviruses (RV), especially RV-A and RV-C groups, are the most frequent viruses detected during an asthma exacerbation, including severe asthma exacerbations with near-fatal and fatal asthma, and allergic asthma patients usually experience more severe and prolonged LRTI symptoms with RV infection compared to non-atopic healthy controls $[38,55,126-128]$. Interestingly, CDHR3 polymorphism is a risk factor for $\mathrm{RV}$-induced severe asthma exacerbations in children [71], possibly because it has recently been shown to be an RV-C receptor [129]. Another study showed that documenting a viral infection in the emergency department was a strong predictor for emergency department re-attendance in children [130]. Impaired interferon responses to RV infection are associated with asthma in both adults and children [105, 106], and are associated with increased RV-induced asthma exacerbation severity [131] Although appealing, the development of a RV vaccine appears highly challenging [132]. However, a proof of concept study on inhaled interferon- $\beta$ as a therapeutic intervention in virus-induced asthma exacerbations only showed benefit in a subgroup of people with moderate/severe asthma [133], implying that further research is needed to investigate the concept of interferon supplementation in asthmatics at exacerbation onset.

\section{Environmental factors: indoor/outdoor air pollution and occupational factors}

Outdoor air pollution is an established risk factor for asthma exacerbations, although the magnitude of effect remains difficult to assess precisely [101]. Diesel exhaust particles and peaks of ambient air pollution, (reflected by, amongst others, high levels of nitrogen dioxide and ozone) were shown as 




ICS: inhaled corticosteroids.

concomitant factors to emergency department attendance in asthmatics but also could be epidemiologically related to asthma exacerbations and deaths [97]. Work-related exacerbations are probably underestimated, whereas many different non-specific irritants could be identified, such as mineral dusts, gas and fumes, etc. [134].

Indoor air pollution comprises second-hand tobacco smoke exposure, which is of special interest in children, and other less well-known contributors, such as volatile organic compounds [135]. Open fireplaces, sick building syndrome, cleaning supplies and household products, and inadequate ventilation are also to be integrated into potential sources of indoor air pollution. We propose to test whether facilitating access to air quality data records may prevent asthma exacerbations. The ELF, while reviewing the present manuscript, supports the use of portable air quality sensors, but more research is needed to identify what substances should be monitored and how best to do this.

Occupational sensitisers and triggers have been causes for concern for many years and efforts have been taken to limit their impact. All task force members in their practice consider it worthwhile facilitating access to free and independent experts in occupational medicine, as well as using $F_{\text {ENO }}$, spirometry, and potentially other relevant diagnostic tests (e.g. induced sputum) at work, especially considering their relatively low direct and indirect costs. More research is needed on occupational triggers and their effect on severe asthma exacerbations. Patients also raised the need to support asthma patients when choosing careers to avoid known and dangerous sensitisers and triggers.

\section{Drugs and irritants/excessive use of $\boldsymbol{\beta}_{2}$-agonists}

Whether drugs known to affect airway smooth muscle tone (such as $\beta$-blockers) are able to trigger an asthma exacerbation is unclear. Non-steroidal anti-inflammatory drugs and aspirin intake in susceptible 
patients induces asthma exacerbations, and low-dose induction of tolerance must be investigated to assess their benefit in preventing exacerbations.

Excessive use of short-acting $\beta_{2}$-agonists (SABAs) in the absence of ICS use has long been linked to hospitalisations and asthma deaths, best exemplified by asthma death epidemics related to high doses of fenoterol reported in New Zealand and other countries [136]. Also, regular use of long-acting $\beta_{2}$-agonists (LABAs) in the absence of ICS has been shown to increase significantly the risk of asthma exacerbations and asthma deaths potentially through a "masking" effect [137-139]. Not only overuse, but also regular use, of SABA (without ICS [140]) has also been associated with paradoxical asthma worsening [52, 141]. The mechanisms involved are not fully understood, but may relate to induction of inflammatory mediators in bronchial epithelial cells by $\beta_{2}$-agonists (both SABA and LABA), when administered in the absence of ICS [142], and/or by a tachyphylaxis phenomenon, but this is still to be demonstrated in vivo [143]. Because several short- and long-acting $\beta_{2}$-agonists are now available, their potential side-effects should be assessed in detail and reported, especially as paradoxical triggers for loss of control and exacerbations. The task force members limit these issues by systematic concomitant ICS use and reassess the patients repeatedly. Most task force members avoid frequent and inappropriate use of repeated or regular high doses of SABA irrespective of the manner of administration (inhaled: pressurised MDI (pMDI), dry powder inhaler or nebulisation) without medical supervision.

\section{Acute management}

\section{Treatment of severe asthma exacerbations}

Despite optimum maintenance therapy and appropriate prevention strategies, severe exacerbations occur, even in patients with mild disease or well-controlled asthma [1, 144]. Therefore, proper assessment and adequate intervention are crucial to stabilise asthma and alleviate symptoms. Although in recent years there has been ample research into the treatment of stable asthma and several new drugs and formulations have been marketed, so far a limited number of treatments are available for asthma exacerbations while limited evidence exists in support of their use [145].

For patients presenting with acute asthma to primary care or the emergency department, the task force members consider that a proper assessment of exacerbation severity is determined based on history, physical examination and objective measurements of lung function and oxygen saturation (please refer to upper section of figure 2) [146]. Arterial blood gas measurements and chest radiography are not included in the guidelines dedicated to the initial assessment, nevertheless they are performed by all the task force members for patients with severe exacerbations and for those who do not respond to initial treatment or are deteriorating [147-149].

Information from patients' history can identify those who are at increased risk of worst outcome and asthma-related death, and prompt arrangements to be made for more frequent evaluation and aggressive treatment (table 2).

Treatment is usually started immediately and simultaneously with the initial evaluation of the patient. The following treatments are usually administered concurrently to achieve the most rapid resolution of the exacerbation and prevent patient deterioration.

\section{Oxygen}

Oxygen is usually delivered by nasal cannula or Venturi mask in order to achieve arterial oxygen saturation of $93-98 \%$. In severe exacerbations, high concentration of oxygen increases the risk of hypercapnia while controlled low flow oxygen therapy is associated with better outcomes [150-152].

\section{Short-acting $\boldsymbol{\beta}_{2}$-agonists}

SABAs intend to resolve bronchospasm and to relieve acute symptoms of asthma, and are usually initially administered every 15-20 min for the first hour during an acute asthma exacerbation. Comparison of pMDI-spacer and nebuliser has shown increased efficiency of SABA delivery via pMDI-spacer and equivalent clinical outcomes $[153,154]$. Data are conflicting whether continuous nebulisation with a SABA is superior to intermittent nebulisation $[155,156]$. In severe asthma exacerbations, continuous nebulisation may be preferred, based on evidence of reduced admissions and improved pulmonary function $[155,157]$. There is no evidence to support the routine use of intravenous $\beta_{2}$-agonists in patients with severe asthma exacerbations [158].

\section{Ipratropium bromide}

Adding ipratropium bromide to SABA decreases rates of hospitalisations and shortens emergency department stays for patients with severe asthma exacerbations [159-161]. Some evidence shows that the 


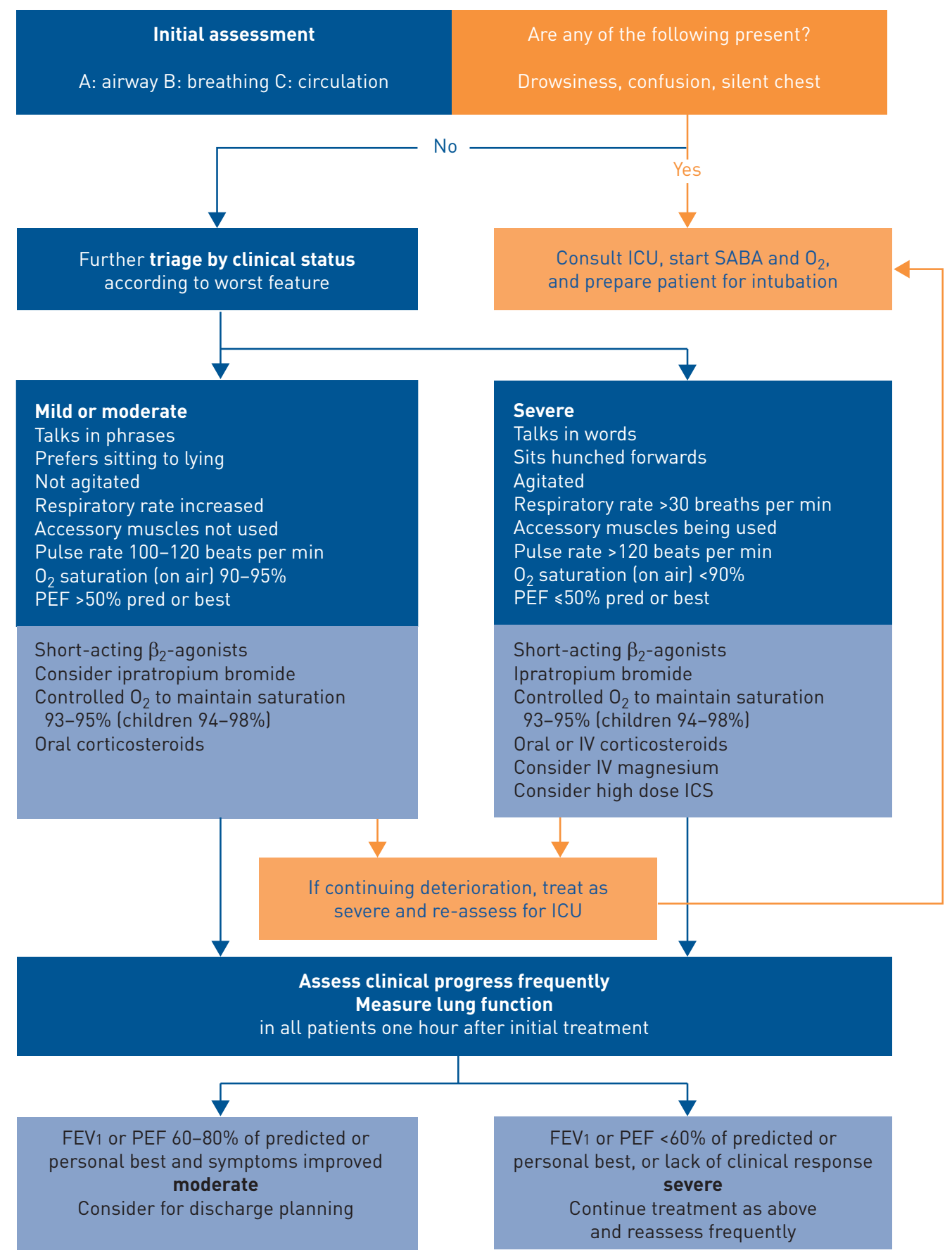

FIGURE 2 Assessment of exacerbation severity based physical signs and objective measurements. PEF: peak expiratory flow; ICU: intensive care unit; SABA: short-acting $\beta_{2}$-agonist; ICS: inhaled corticosteroid; FEV ${ }_{1}$ : forced expiratory volume in $1 \mathrm{~s}$. Reproduced from the Global Initiative for Asthma Report with permission from the publisher [1].

use of combination ipratropium/ $\beta$-agonist therapy in acute asthmatic exacerbations provides benefit without increased risk of adverse events [161].

\section{Corticosteroids}

Early administration of systemic corticosteroids for the treatment of asthma exacerbations is considered a standard of care and is recommended worldwide to be given to the patient within $1 \mathrm{~h}$ of presentation $[162,163]$. A systematic review showed that the use of systemic corticosteroids reduces the rate of hospital admission in emergency department settings, especially in patients with severe asthma and those not currently receiving corticosteroids [164]. 
The optimal dose for systemic corticosteroids in asthma exacerbations remains to be established. Doses above $2 \mathrm{mg} \cdot \mathrm{kg}^{-1}$ or $60-80 \mathrm{mg} \cdot \mathrm{day}^{-1}$ do not add benefit to improving lung function, rates of hospital admission or length of hospital stay $[162,165]$. Furthermore, no differences are found between oral and intravenous administration of comparable corticosteroid doses [166, 167]. Thus, daily doses of OCS equivalent to $50 \mathrm{mg}$ prednisolone as a single morning dose, or $200 \mathrm{mg}$ hydrocortisone in divided doses, are adequate for most patients [1]. A short course of 5 days OCS after emergency department treatment of acute asthma exacerbations has been shown to reduce the rate of relapse [1, 164]. Courses longer than 5 days or a dose tapering did not provide additional benefit, while increasing side-effects [168, 169].

The role of ICS in the management of asthma in the emergency department remain unclear and their use in severe asthma exacerbations is not evenly adopted [170].

\section{Other treatments}

None of the task force members use intravenous aminophylline and theophylline in the management of asthma exacerbations, in view of their poor efficacy and safety profile [1]. Intravenous magnesium sulphate (given as a single 2-g infusion over $20 \mathrm{~min}$ ) has been shown to reduce hospital admissions in severe exacerbations and in patients who fail to respond to initial treatment [171, 172]. Evidence does not support a role of antibiotics in asthma exacerbations unless there is strong presumption of lung infection $[1,173]$. Other associated advice for management (hydration, physiotherapy, avoid exercise, etc.) are poorly evidenced [174]. It is noteworthy that exercise outside an episode of exacerbation should be largely supported as it was shown to prevent exacerbations and to improve control [175].

\section{Prevention}

Here we describe the evidence for current therapies available across the severity spectrum of asthma, licensed biologicals and those in phase 3 clinical development.

\section{Current small molecule asthma therapies \\ Corticosteroids}

Extensive data support the role of ICS in asthma with increasing dose reducing exacerbation frequency [1, $176,177]$. Increasing the ICS dose four-fold at the onset of exacerbation symptoms reduced the need for systemic corticosteroids by $19 \%$ [178]. No randomised controlled trials exist of prednisolone versus placebo as add-on therapy in severe asthma [179]. Registry data suggested that maintenance oral corticosteroid use was associated with reduced exacerbations among a cohort of patients with severe asthma [180]. In a small study, high-dose intramuscular triamcinolone reduced hospital admissions and emergency department attendance; however, the long-term side-effect profiles of systemic steroids have to be kept in mind. The task force members use maintenance OCS as a therapeutic strategy for reducing exacerbations as a less preferred option and suggest this practice be supervised in expert referral centres familiar with the management and prevention of OCS side-effects [181].

Presence of eosinophilic inflammation predicts a good response to corticosteroids in airway disease [182184]. Tailoring corticosteroid dose to control sputum eosinophilia in asthma has achieved marked reductions in exacerbation rates $[16,18,185]$ and the ERS/ATS guideline advocates measurement of eosinophilic inflammation in severe asthma [3].

Given the superiority of an on-demand ICS-containing regimen in two separate trials performed in patients with mild asthma in reducing the risk of exacerbation [186, 187], later confirmed in a real-life setting [188], the last GINA update promotes this strategy as early as step 1, acknowledging the obvious inflammatory nature of the disease and in particular during episodes of poor control that precedes exacerbation.

The management of asthma using a sputum-guided adjustment of the daily dose of ICS was shown to be efficient in preventing exacerbations in expert centres where induced sputum cytology can be assessed routinely, in patients able to provide an adequate sample within the safety margins of induction $[16,18]$.

Long-acting $\beta_{2}$-agonists added to ICS

ICS-LABA combination therapy is standard in severe asthma and the addition of a LABA to ICS reduces exacerbation frequency in asthma $[1,176,177]$. The task force echoed recurrent warnings regarding monotherapy with LABA in asthma [189].

Long-acting muscarinic antagonists added to ICS

Tiotropium, as add-on therapy for asthmatics uncontrolled while treated with ICS and LABA, increased time to first exacerbation by 56 days versus placebo $(p=0.03)$ [190]. A Cochrane review of long-acting 
muscarinic antagonist added to ICS versus ICS alone across all severities of asthma showed a reduction in exacerbations requiring oral corticosteroids, and a trend towards reduction in hospital admissions [191].

Leukotriene receptor antagonists

A systematic review of leukotriene receptor antagonists (LTRAs) identified a significant reduction in exacerbations when used as monotherapy compared to placebo, but no effect on exacerbation rates when used in patients already taking ICS [192]. Whether LTRAs reduce severe exacerbations in severe asthmatics is unknown.

\section{Theophylline}

A study comparing ICS/LABA and theophylline versus ICS/LABA and placebo found a significant reduction in severe exacerbations in the theophylline group in asthma patients who were treatment-naïve [193]. Whether theophylline affects exacerbation frequency in severe asthma is unknown. Most task force members do not use theophylline as an add-on therapy for preventing exacerbations.

\section{Antimicrobials}

In a large clinical trial, thrice-weekly azithromycin in moderate-to-severe asthma resulted in a $41 \%$ reduction in severe exacerbations with benefits independent of inflammatory phenotype [194], in contrast to a previous sub-analysis in severe asthma patients where the benefits were limited to the non-eosinophilic subgroup [195]. Of note, worldwide, azithromycin is not approved to the best of knowledge in this indication. Anti-fungal agents in fungal-sensitised severe asthma not meeting criteria for allergic bronchopulmonary aspergillosis demonstrated no impact on severe exacerbations [196].

\section{Immunosuppressants}

Data reporting exacerbations was limited in a Cochrane review examining the corticosteroid sparing effect of cyclosporin in severe oral corticosteroid dependent asthma [197]. A similar review examining the corticosteroid sparing effects of methotrexate in severe asthma did not demonstrate a beneficial effect on exacerbation rates [198].

\section{Allergen avoidance and immunotherapy}

Allergen avoidance advice is standard clinical practice in severe asthma [1, 176, 177], but allergen avoidance has shown controversial benefit [199], possibly due to difficulty in achieving this effectively. Allergen immunotherapy strategies in asthma report some benefit for reducing symptoms and corticosteroid usage but have not been tested in severe asthma [200]. It is unknown whether measures such as nocturnal temperature controlled laminar flow will be effective. Reductions in airway inflammation are reported in atopic asthma [201] and studies in severe asthma are ongoing [202].

\section{Current biological therapies for asthma}

The phase 3 randomised controlled trials for currently available biological therapy in asthma, except for anti-IgE as more established, are summarised in table 4 , including phase $2 \mathrm{~b}$ studies that were considered pivotal for registration. Studies in less severe asthma with a very low event rate, open-label extensions that confirmed earlier findings and studies that did not report exacerbations were not included.

\section{Anti-IgE: omalizumab}

A Cochrane review of omalizumab as add-on therapy in moderate-to-severe asthma reported a reduction (OR 0.55, 95\% CI 0.42-0.60; 10 studies, 3261 participants) in severe exacerbations [203]; however, subgroup analysis of severe asthma alone did not demonstrate a clear benefit. Further clinical trials remain ongoing [201].

\section{Anti-IL-5: mepolizumab and reslizumab}

Mepolizumab reduces exacerbation frequency by $\sim 50 \%[5,65,204-206]$ and reduces the requirement for maintenance oral corticosteroid [206]. Benefits were observed in severe asthmatics with blood eosinophils $>150$ cells $\mu \mathrm{L}^{-1}$ [207], with greatest exacerbation frequency reductions seen with increasing eosinophilic inflammation. These beneficial effects were not sustained over the 12 months following treatment withdrawal [208], while it was the case when treatment was maintained [209]. This exacerbation rate reduction was also achieved while tapering OCS in long-term OCS users [206]. Reslizumab demonstrated a reduction in severe exacerbations in severe asthmatics with a baseline blood eosinophil count $>400$ cells $\mu \mathrm{L}^{-1}$ [210]. Improvements were greatest in those with GINA step 5 disease [211]. 
TABLE 4 Pivotal phase 3 randomised clinical trials of licensed biological agents (excluding anti-lgE)

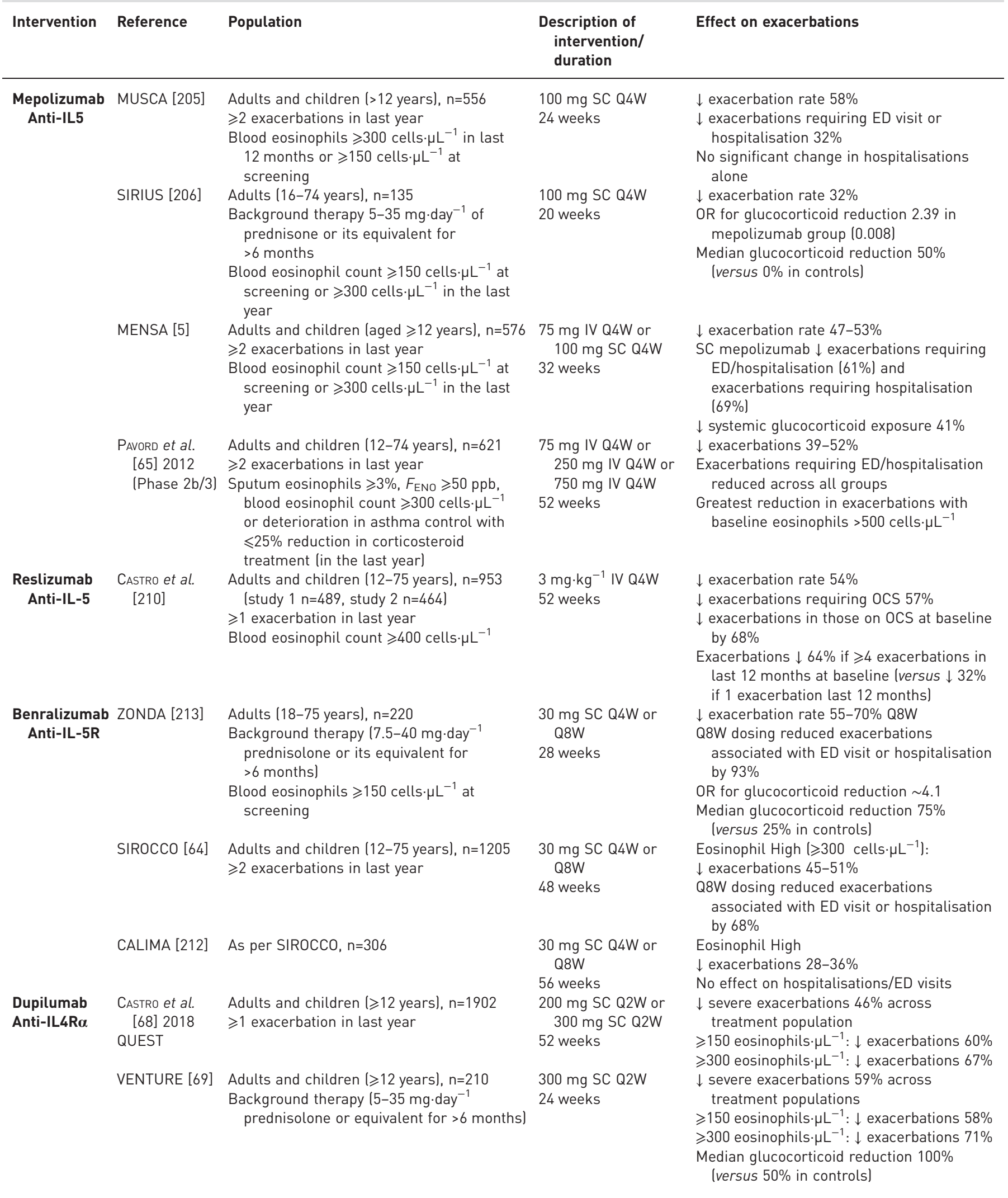

ED: emergency department; $F_{\mathrm{ENO}}$ : exhaled fraction of nitric oxide; OCS: oral corticosteroids. 
TABLE 5 Research needs and knowledge gaps

Item Research needs $\quad$ Type of study design $\quad \begin{gathered}\text { Type of outcomes that need to be } \\ \text { assessed }\end{gathered}$

\section{Definition of severe exacerbation \\ Definition of severe exacerbation \\ Definition of severe exacerbation Strategy}

Strategy

Risk factor/ trigger

Risk factor/ trigger

\section{Risk factor/ trigger}

\section{Risk factor/ trigger \\ Risk factor/ trigger \\ Risk factor/ trigger \\ Risk factor/ trigger}

$\begin{array}{cc}\begin{array}{c}\text { Risk factor/ } \\ \text { trigger }\end{array} & \begin{array}{c}\text { To assess the benefits of using air quality } \\ \text { sensors }\end{array} \\ \begin{array}{c}\text { Risk factor/ } \\ \text { trigger }\end{array} & \begin{array}{c}\text { To assess the benefits of more accurately } \\ \text { evidence the role of occupational } \\ \text { triggers }\end{array} \\ \begin{array}{c}\text { Risk factor/ } \\ \text { trigger }\end{array} & \begin{array}{l}\text { To assess the preventive benefits of } \\ \text { convincingly support patient when } \\ \text { choosing careers }\end{array} \\ \begin{array}{c}\text { To assess the exact role of drugs in severe } \\ \text { exacerbations (incidence, dose, }\end{array} \\ \text { trigger } & \begin{array}{l}\text { diagnosis, prevention) } \\ \end{array}\end{array}$
Treatment of To define the value of chest radiography severe exacerbation
and arterial blood gases in acute management compared to other risk factors at the individual level

To assess the benefits and risks of genetic analysis awareness at the individual level to predict severe exacerbation and asthma trajectory

To more accurately know the mechanisms, rate and risk factors of deaths attributable to severe exacerbations that occurred despite an optimal preventive strategy and acute management

To identify and weight all risk factors associated with death, ICU, ED and frequent exacerbations

To identify tools for assessing/improving adherence

To assess the benefits of eHealth-connected devices to prevent severe exacerbation

to assess tools/resources/methods le.g. shared decision making, systematic multidisciplinary approaches, referral to asthma centres) to improve patient-HCP partnership

o assess the benefits of using air quality comparing strategies
Re-analysis of RCT and real-life trials where diaries and home monitoring were used Registries and cohorts

Re-analysis of RCT and real-life trials where diaries and home monitoring were used Registries and cohorts

Retrospective analysis of databases of exacerbations

Randomised controlled trials comparing conventional versus self-monitoring strategy

Randomised controlled trials

Prospective cohort studies integrating all risk factors

Rates of OCS bursts $\geqslant 5$ days, ED, admissions, need for ICU

Rates of OCS bursts $\geqslant 5$ days, ED, admissions, need for ICU

Short term outcomes: admission, ICU, intubation, deaths, treatment related adverse events

Rates of OCS bursts $\geqslant 5$ days, ED, admissions, need for ICU

Rates of OCS bursts $\geqslant 5$ days, ED, admissions, need for ICU

Rates of OCS bursts $\geqslant 5$ days, ED, admissions, need for ICU

Severe exacerbation rates in patients and relatives, in particular in children with high risk scores (familial risk, patients already admitted in ICU)

Biology, pathology

Multiple exhaustive reviews of asthma deaths Worldwide collection of cases where death occurred despite optimal management

Cohorts and registries of compelling cases

RCT comparing strategies

RCT comparing strategies

Studies assessing changes in patient-HCP partnership through training, education programmes, etc.

RCT in selected populations

Basic science, models, psychoand sociology

Prospective cohorts with randomised strategies

Prospective cohorts with randomised strategies Models of exposition in animals and cell models

RCTs
Rates of OCS bursts $\geqslant 5$ days, ED, admissions, need for ICU

Rates of OCS bursts $\geqslant 5$ days, ED, admissions, need for ICU

Rates of OCS bursts $\geqslant 5$ days, ED, admissions, need for ICU

Parallel studies associating changes in patient-HCP partnership with changes in severe exacerbation rates

Rates of OCS bursts $\geqslant 5$ days, ED, admissions, need for ICU

Rooms of exposition with inflammatory/ lung function monitoring HRQOL

In teenagers/young adults and in people changing of occupation

Prospective recording of severe exacerbation

Maximal documentation of each event

Dedicated populations such as ED attending 
TABLE 5 Continued

\begin{tabular}{|c|c|c|c|}
\hline Item & Research needs & Type of study design & $\begin{array}{l}\text { Type of outcomes that need to be } \\
\text { assessed }\end{array}$ \\
\hline $\begin{array}{l}\text { Treatment of } \\
\text { severe } \\
\text { exacerbation }\end{array}$ & $\begin{array}{l}\text { To establish an optimal scheme for SABA } \\
\text { administration }\end{array}$ & $\begin{array}{l}\text { RCTs comparing different } \\
\text { strategies of SABA } \\
\text { administration (dose, route, } \\
\text { frequency, duration, associated } \\
\text { treatment) }\end{array}$ & $\begin{array}{l}\text { Rates of OCS bursts } \geqslant 5 \text { days, ED } \\
\text { discharge versus admissions, need for } \\
I C U \text {, adverse events }\end{array}$ \\
\hline $\begin{array}{l}\text { Treatment of } \\
\text { severe } \\
\text { exacerbation }\end{array}$ & $\begin{array}{l}\text { To assess the benefits of hydration, } \\
\text { physiotherapy, exercise avoidance } \\
\text { during exacerbation; optimal time to go } \\
\text { back to exercise }\end{array}$ & RCTs, comparative studies & $\begin{array}{l}\text { Rates of relapses, speed of recovery, } \\
\text { adverse events, quality of life }\end{array}$ \\
\hline Prevention & $\begin{array}{l}\text { To assess whether LTRAs add-on reduce } \\
\text { severe exacerbations in severe } \\
\text { asthmatics }\end{array}$ & RCTs & $\begin{array}{l}\text { Rates of OCS bursts } \geqslant 5 \text { days, ED } \\
\text { discharge versus admissions, need for } \\
I C U \text {, adverse events }\end{array}$ \\
\hline Prevention & $\begin{array}{l}\text { to assess the use of biologics in the } \\
\text { setting of acute exacerbation }\end{array}$ & RCTs & $\begin{array}{l}\text { Rates of relapses, speed of recovery, } \\
\text { disease associated and hospital } \\
\text { acquired-adverse events, quality of life }\end{array}$ \\
\hline $\begin{array}{l}\text { From the } \\
\text { patients' } \\
\text { perspective }\end{array}$ & $\begin{array}{l}\text { Overall, to find treatments for patients not } \\
\text { responding well to currently available } \\
\text { medications and treatments plans }\end{array}$ & $\begin{array}{l}\text { RCTs in non eligible patients to } \\
\text { existing drugs (low T2, failure of } \\
\text { currently available biologics for } \\
\text { example) }\end{array}$ & $\begin{array}{l}\text { Rates of OCS bursts } \geqslant 5 \text { days, ED } \\
\text { discharge versus admissions, need for } \\
I C U \text {, adverse events }\end{array}$ \\
\hline
\end{tabular}

OCS: oral corticosteroids; RCT: randomised controlled trial; ED: emergency department; ICU: intensive care unit; HCP: healthcare provider; HRQOL: health-related quality of life; SABA: short-acting $\beta_{2}$-agonist; LTRA: leukotriene receptor antagonist.

\section{Anti-IL-5R: benralizumab}

Benralizumab reduces severe exacerbations $[64,212,213]$ in those with a blood eosinophil count $>300$ cells $\mu \mathrm{L}^{-1}$. A priori sub-analyses using an eosinophil cut-off of 150 cells $\mu \mathrm{L}^{-1}$ also demonstrated significant reductions in exacerbation rates [214], although higher blood eosinophils and more frequent exacerbations predicted greater benefits [215]. This exacerbation rate reduction was also achieved while tapering OCS in long-term OCS users [213]. A study of benralizumab administered in the setting of acute asthma exacerbation [66] reported a positive impact on recovery rates, however further work would be required to define the use of biologicals in this setting.

\section{Bronchial thermoplasty}

In 190 subjects who received bronchial thermoplasty (BT) versus 98 who underwent sham procedures, severe exacerbations were reduced by $32 \%$ in the 3-12 months post-therapy with an increase in exacerbation events in the peri-procedural period [21]. This reduction in exacerbations was maintained over a 5 year follow-up period [216]. BT is currently performed only in trained centres for both managing severe asthma and handling BT.

\section{Emerging biological therapies}

Anti-IL-4R: dupilumab

Dupilumab reduced severe exacerbations in all-comers irrespective of their atopic status, with the greatest reduction in those with elevated $F_{\mathrm{ENO}}$ and/or eosinophilic inflammation, and reduced OCS requirement for severe asthmatics receiving maintenance OCS [68, 217, 218]. Studies of IL-4 inhibition alone, and more recently of the anti-IL-13 biologicals lebrikizumab [219] and tralokinumab [220], have failed to meet their primary end-points of exacerbation reduction, suggesting that inhibition of both IL-4 and -13 , as with anti-IL-4R, is necessary to observe sufficient clinical efficacy for this aspect of the disease.

Anti-TSLP: tezepelumab

A recent phase II trial investigated the impact of tezepelumab on exacerbation rates in 584 moderate-to-severe asthmatics, showing a $60-70 \%$ reduction in exacerbations in all-comers across dosing 
TABLE 6 Summary of key points

\begin{tabular}{|c|c|c|}
\hline Section & Section title & Key points \\
\hline 2 & Triggers and risk factors & $\begin{array}{l}\text { Within trajectories of asthma, the frequent exacerbator phenotype is a reality, and is } \\
\text { more frequently associated with a T2 pattern }\end{array}$ \\
\hline $2 A$ & $\begin{array}{l}\text { Assessment of risk: what is cause and what is } \\
\text { effect? }\end{array}$ & $\begin{array}{l}\text { T2 inflammation and lack of adequate treatment more likely exposes to exacerbation } \\
\text { rather than the opposite }\end{array}$ \\
\hline $2 C$ & $\begin{array}{l}\text { Risk factors and epidemiology, pheno/geno/ } \\
\text { endotypes }\end{array}$ & $\begin{array}{l}\text { Susceptibility to severe exacerbations is not always shared with susceptibility to } \\
\text { asthma severity } \\
\text { Low T2 asthma and other newly identified endotypes are currently orphans of } \\
\text { targeted drugs }\end{array}$ \\
\hline $2 D$ & $\begin{array}{l}\text { Typology: gender and psychosocial factors, } \\
\text { perception, compliance/adherence }\end{array}$ & $\begin{array}{l}\text { Multidisciplinary approaches may help in identifying and managing better patients at } \\
\text { risk of death, ICU admission and severe exacerbations }\end{array}$ \\
\hline $2 G$ & $\begin{array}{l}\text { Drugs and irritants/excessive use of } \\
\beta_{2} \text {-agonists }\end{array}$ & Dangers of high SABA use includes worsening of asthma itself \\
\hline 3 & Acute management & $\begin{array}{l}\text { Systemic corticosteroids and bronchodilators are still the cornerstones of the acute } \\
\text { management } \\
\text { Because some asthma deaths are not preventable, there is a place to develop new } \\
\text { drugs on top of standard of care }\end{array}$ \\
\hline 4 & Prevention & $\begin{array}{l}\text { Inhaled corticosteroids with or without bronchodilators and, in eligible patients with } \\
\text { more severe disease, biological therapies prevent severe exacerbations }\end{array}$ \\
\hline 5 & ELF patient perspective & $\begin{array}{l}\text { The currently available treatments and supports are not working well enough for all } \\
\text { More research and partnership are needed }\end{array}$ \\
\hline
\end{tabular}

OCS: oral corticosteroids; ICU: intensive care unit; SABA: short-acting $\beta_{2}$-agonist.

regimens [221]. Effects were observed irrespective of markers of T2 inflammation, although substantial reductions in these measures were noted, suggesting that targeting upstream cytokine pathways may reduce exacerbations across inflammatory profiles.

CRTH2 antagonists, anti-IL-17 and others

ILC2 are now seen as the pivotal cells of T2 airway inflammation. Because they specifically express the PGD2 receptor DP2 or CRTH2, a proof of concept study showed that anti-DP2 treatment could significantly reduce the blood eosinophil count [222]. Whether this will be sufficient for preventing exacerbations is the aim of a larger ongoing phase 3 trial.

The IL33-ST2 axis is also specifically targeting ILC2 [223] and pivotal studies are ongoing. In non T2 asthma, the relevance of blocking IL-17 for preventing exacerbations is also currently being tested [224].

\section{Conclusion}

Reduction and ultimately elimination of severe exacerbations in severe asthma remains an important therapeutic target. In addition to corticosteroids and allergen avoidance/immunotherapy, the biologicals targeting T2 immunity and eosinophilic inflammation (anti-IgE, IL-5, IL-4R and TSLP) reduce exacerbations. Whether other therapies that reduce eosinophilic inflammation, such as anti-DP2, will demonstrate a similar efficacy remains to be determined. Beyond T2 inflammation, macrolide antibiotics and bronchial thermoplasty may have a role, but reducing severe exacerbations in non-T2 severe asthma remains an unmet need, although the scale of its importance once T2-mediated disease is adequately treated is uncertain.

\section{Conclusion and ELF patient perspectives}

Preventing severe exacerbations in asthma is very important from the perspective of people with asthma. Too many patients still die from a severe exacerbation, whereas these deaths are likely preventable. In 
some countries, asthma and respiratory deaths are still increasing, especially in non-severe and moderate asthma [84]. Why this is happening still needs to be explored but facilitating access to care and medications would probably be of benefit.

- In all types of asthma: it is important to remain aware that severe exacerbations don't just happen in patients with the more severe types of asthma.

- Exacerbations, and especially recurrent exacerbations, are very debilitating for patients. More research is needed to avoid exacerbations and to break the cycle of recurrent exacerbations. The medications and treatment plans that are available at this time do not seem to be working well enough for all patients.

- Adherence: patients and physicians need to work together on improving adherence. Good communication between physician and patient is key. There are many factors that impede adherence for patients. Some straight-forward ways to support patients can be implemented easily, such as having dose-counters on all inhalators. It can be more challenging to address patients developing additional behaviour: for example, those that find it difficult to incorporate different medications into their daily routine, or subsequently, if their routine needs to change again, because of an exacerbation or increased breathlessness. All aspects require continuous positive attention from physicians.

- Indoor and outdoor environmental factors: the advice to avoid environmental factors is an additional burden, moreover because it is extremely complex to put into practice for patients. More and better advice needs to be given to patients regarding living conditions, occupational choices, etc.

- Working together with patients in improving their asthma care is key. Many patients have good knowledge of their asthma and their reaction to medications. Not all patients have this insight and not all patients are able to manage their asthma on a daily basis. We all need personalised help. E-health can support some patients, but only if these solutions are developed with patients and are sufficiently flexible and personalised.

Research needs and knowledge caps identified throughout this task force are summarised in table 5, and key points summarised in table 6 .

Conflict of interest: A. Bourdin reports personal and institutional fees for advisory board work from AstraZeneca, Novartis, GSK, Boehringher Ingelheim, Chiesi, Actelion, Pfizer and Teva, outside the submitted work. L. Bjermer has nothing to disclose. C. Brightling reports grants and personal fees for consultancy from GlaxoSmithKline, AstraZeneca/ Medimmune, Novartis, Chiesi, Roche/Genentech and Boehringer Inglheim, personal fees for consultancy from Vectura, Theravance, PreP, Gilead, Sanofi/Regeneron, Teva, Gossamer and 4DPharma, grants from Pfizer and Mologic, outside the submitted work. G.G. Brusselle reports personal fees for advisory board work and lectures from AstraZeneca, Boehringer Ingelheim, Chiesi, GlaxoSmithKline, Novartis and Teva, personal fees for advisory board work from Sanofi, outside the submitted work. P. Chanez reports research grants and personal fees for consultancy, advisory board work and lectures from ALK, Almirall, Boehringer Ingelheim, GSK, AstraZeneca, Novartis, TEVA and Chiesi, grants from AMU, outside the submitted work. K.F. Chung has received honoraria for participating in advisory board meetings of GSK, AZ, Novartis, Merck, BI and TEVA regarding treatments for asthma and COPD, and has also been renumerated for speaking engagements. A. Custovic reports personal fees for consultancy from Novartis, Regeneron/Sanofi, Boehringer Ingelheim and Philips, personal fees for lectures from Thermo Fisher Scientific and Novartis, outside the submitted work. Z. Diamant reports personal fees from AstraZeneca and Sanofi-Genzyme, during the conduct of the study; personal fees from Aquilon, ALK, Boehringer Ingelheim, Gilead, Hal Allergy and MSD, outside the submitted work; and in addiction to academic affiliations, also works at a phase I/II unit performing clinical studies for different biotech and pharma companies. S. Diver has nothing to disclose. R. Djukanovic reports receiving fees for lectures at symposia organised by Novartis, AstraZeneca and TEVA, consultation for TEVA and Novartis as member of advisory boards, and participation in a scientific discussion about asthma organised by GlaxoSmithKline; in addition, is a co-founder and current consultant, and has shares in, Synairgen, a University of Southampton spin out company. D. Hamerlijnck has nothing to disclose. I. Horvath reports personal fees from AstraZeneca, Berlin-Chemie, Boehringer Ingelheim, Chiesi, GSK, Novartis, CSL-Behring and Roche, outside the submitted work. S.L. Johnston reports personal fees for advisory board work from Therapeutic Frontiers and Virtus Respiratory Research, personal fees for consultancy from Myelo Therapeutics GmbH, Concert Pharmaceuticals, Bayer, Gerson Lehrman Group, resTORbio, Bioforce, Materia Medical Holdings, PrepBio Pharma, Pulmotect, Virion Health and Lallemand Pharma, personal and insititutional fees for consultancy from Synairgen, Novartis, Boehringer Ingelheim and Chiesi; and has received personal fees for the following patents planned, issued or pending: transgenic animal models of HRV with human ICAM-1 sequences (UK patent application number 02167 29.4, and international patent application number PCT/EP2003/ 007939); anti-virus therapy for respiratory diseases (UK patent application number GB 0405634.7); interferon-beta for anti-virus therapy for respiratory diseases (international patent application number PCT/GB05/50031); interferon lambda therapy for the treatment of respiratory disease (UK patent application number 6779645.9, granted); induction of cross-reactive cellular response against rhinovirus antigens (European patent number 13305152), outside the submitted work. F. Kanniess reports personal fees for lectures and advisory board work from AstraZeneca, Novartis, Mundipharma and TEVA, outside the submitted work. N. Papadopoulos reports personal fees for advisory board work and lectures from Novartis, Nutricia, HAL, personal fees from Menarini/Faes Farma and Mylan/Meda, personal fees for lectures from Sanofi, Biomay, MSD, ASIT Biotech and Boehringer Ingelheim, personal fees for advisory board work from AstraZeneca and GSK, grants from Gerolymatos International SA and Capricare, outside the submitted work. A. Papi reports grants, personal fees for lectures, advisory board work and consultancy, and travel expenses reimbursement from AstraZeneca, Boehringer Ingelheim, Chiesi Farmaceutici, GlaxoSmithKline and Teva, personal fees for advisory board work and consultancy from Sanofi/Regeneron, personal fees for lectures and travel expenses 
reimbursement from Zambon and Novartis, personal fees for lectures, advisory board work and consultancy, and travel expenses reimbursement from Mundipharma, personal fees for lectures and advisory board work, and travel expenses reimbursement Almirall, grants, personal fees for lectures and travel expenses reimbursement from Menarini, grants from Fondazione Maugeri, grants from Fondazione Chiesi Farmaceutici, outside the submitted work. R.J. Russell has nothing to disclose. D. Ryan reports personal fees for advisory board work from GSK and Trudell Medical, personal fees for advisory board work and lectures from AZ, personal fees for lectures from Mylan and Chiesi, personal fees for consultancy from Optimum Patient Care, outside the submitted work. K. Samitas has nothing to disclose. T. Tonia acts as ERS methodologist. E. Zervas reports personal fees consultancy and lectures from Astra, Bristol-Myers Squibb, Chiesi, GSK, Elpen, Merck, MSD, Novartis, Menarini and Pfizer, non-financial support for travel, accommodation and meeting expenses from Astra, Bristol-Myers Squibb, Galenica, Chiesi, Elpen, Novartis, Menarini and Roche, outside the submitted work. M. Gaga reports grants and personal fees from AZ, grants from BI, Elpen, Novartis and Menarini, personal fees from BMS, MSD, Chiesi and Pharmaten, outside the submitted work.

\section{References}

1 Global Initiative for Asthma (GINA). 2018 GINA Report: Global Strategy for Asthma Management and Prevention. https://ginasthma.org/2018-gina-report-global-strategy-for-asthma-management-and-prevention/ Date last accessed: 19 Sept 2018.

2 Salmeron S, Liard R, Elkharrat D, et al. Asthma severity and adequacy of management in accident and emergency departments in France: a prospective study. Lancet 2001; 358: 629-635.

3 Chung KF, Wenzel SE, Brozek JL, et al. International ERS/ATS guidelines on definition, evaluation and treatment of severe asthma. Eur Respir J 2014; 43: 343-373.

4 Chipps BE, Haselkorn T, Paknis B, et al. More than a decade follow-up in patients with severe or difficult-to-treat asthma: The Epidemiology and Natural History of Asthma: Outcomes and Treatment Regimens (TENOR) II. J Allergy Clin Immunol 2018; 141: 1590-1597.e9.

5 Ortega HG, Liu MC, Pavord ID, et al. Mepolizumab treatment in patients with severe eosinophilic asthma. $N$ Engl J Med 2014; 371: 1198-1207.

6 Nasser S. An imperfect "PAST". Lessons learned from the National Review of Asthma Deaths (NRAD) UK. Respir Res 2016; 17: 87.

7 Levy ML, Andrews R, Buckingham R, et al. Why Asthma Still Kills: the National Review of Asthma Deaths (NRAD). Confidential enquiry report. London, Healthcare Quality Improvement Partnership/Royal College of Physicians, 2014

8 Bousquet J, Khaltaev N, Cruz A, et al. International European Respiratory Society/American Thoracic Society guidelines on severe asthma. Eur Respir J 2014; 44: 1377-1378.

9 Custovic A, Johnston SL, Pavord I, et al. EAACI position statement on asthma exacerbations and severe asthma. Allergy 2013; 68: 1520-1531.

10 Bush A, Zar HJ. WHO universal definition of severe asthma. Curr Opin Allergy Clin Immunol 2011; 11: 115-121.

11 Bousquet J, Mantzouranis E, Cruz AA, et al. Uniform definition of asthma severity, control, and exacerbations: document presented for the World Health Organization Consultation on Severe Asthma. J Allergy Clin Immunol 2010; 126: 926-938.

12 Reddel HK, Taylor DR, Bateman ED, et al. An official American Thoracic Society/European Respiratory Society statement: asthma control and exacerbations: standardizing endpoints for clinical asthma trials and clinical practice. Am J Respir Crit Care Med 2009; 180: 59-99.

13 Miller MK, Lee JH, Blanc PD, et al. TENOR risk score predicts healthcare in adults with severe or difficult-to-treat asthma. Eur Respir J 2006; 28: 1145-1155.

14 Price DB, Trudo F, Voorham J, et al. Adverse outcomes from initiation of systemic corticosteroids for asthma: long-term observational study. J Asthma Allergy 2018; 11: 193-204.

15 O'Byrne PM, Pedersen S, Lamm CJ, et al. Severe exacerbations and decline in lung function in asthma. Am J Respir Crit Care Med 2009; 179: 19-24.

16 Green RH, Brightling CE, McKenna S, et al. Asthma exacerbations and sputum eosinophil counts: a randomised controlled trial. Lancet 2002; 360: 1715-1721.

17 Pauwels RA, Löfdahl CG, Postma DS, et al. Effect of inhaled formoterol and budesonide on exacerbations of asthma. Formoterol and Corticosteroids Establishing Therapy (FACET) International Study Group. N Engl J Med 1997; 337: 1405-1411.

18 Jayaram L, Pizzichini MM, Cook RJ, et al. Determining asthma treatment by monitoring sputum cell counts: effect on exacerbations. Eur Respir J 2006; 27: 483-494.

19 Demoly P, Crestani B, Leroyer C, et al. Control and exacerbation of asthma: a survey of more than 3000 French physicians. Allergy 2004; 59: 920-926.

20 Fuhlbrigge A, Peden D, Apter AJ, et al. Asthma outcomes: exacerbations. J Allergy Clin Immunol 2012; 129: S34-S48.

21 Castro M, Rubin AS, Laviolette M, et al. Effectiveness and safety of bronchial thermoplasty in the treatment of severe asthma: a multicenter, randomized, double-blind, sham-controlled clinical trial. Am J Respir Crit Care Med 2010; 181: 116-124.

22 Murphy VE, Clifton VL, Gibson PG. The effect of cigarette smoking on asthma control during exacerbations in pregnant women. Thorax 2010; 65: 739-744.

23 Sont JK, Willems LN, Bel EH, et al. Clinical control and histopathologic outcome of asthma when using airway hyperresponsiveness as an additional guide to long-term treatment. The AMPUL Study Group. Am J Respir Crit Care Med 1999; 159: 1043-1051.

24 Petsky HL, Cates CJ, Li A, et al. Tailored interventions based on exhaled nitric oxide versus clinical symptoms for asthma in children and adults. Cochrane Database Syst Rev 2009: CD006340.

25 Smith AD, Cowan JO, Brassett KP, et al. Use of exhaled nitric oxide measurements to guide treatment in chronic asthma. N Engl J Med 2005; 352: 2163-2173.

26 Szefler SJ, Mitchell H, Sorkness CA, et al. Management of asthma based on exhaled nitric oxide in addition to guideline-based treatment for inner-city adolescents and young adults: a randomised controlled trial. Lancet 2008; 372: 1065-1072. 
Powell H, Murphy VE, Taylor DR, et al. Management of asthma in pregnancy guided by measurement of fraction of exhaled nitric oxide: a double-blind, randomised controlled trial. Lancet 2011; 378: 983-990. Petsky HL, Cates CJ, Kew KM, et al. Tailoring asthma treatment on eosinophilic markers (exhaled nitric oxide or sputum eosinophils): a systematic review and meta-analysis. Thorax 2018; 73: 1110-1119.

29 Yii ACA, Tan JHY, Lapperre TS, et al. Long-term future risk of severe exacerbations: Distinct 5-year trajectories of problematic asthma. Allergy 2017; 72: 1398-1405.

30 Miller MK, Lee JH, Miller DP, et al. Recent asthma exacerbations: A key predictor of future exacerbations. Respir Med 2007; 101: 481-489.

31 Heikkilä K, Madsen IEH, Nyberg ST, et al. Job strain and the risk of severe asthma exacerbations: a meta-analysis of individual-participant data from 100000 European men and women. Allergy 2014; 69: 775-783.

Bjermer L. The role of small airway disease in asthma. Curr Opin Pulm Med 2014; 20: 23-30.

Gelb AF, Schein A, Nussbaum E, et al. Risk factors for near-fatal asthma. Chest 2004; 126: 1138-1146.

Alvarez GG, Fitzgerald JM. A systematic review of the psychological risk factors associated with near fatal asthma or fatal asthma. Respiration 2007; 74: 228-236.

35 Alvarez GG, Schulzer M, Jung D, et al. A systematic review of risk factors associated with near-fatal and fatal asthma. Can Respir J 2005; 12: 265-270.

36 Butler C, Heaney LG. Risk factors of frequent exacerbations in difficult-to-treat asthma. Eur Respir J 2006; 27: 1324-1325.

37 de Groot JC, Amelink M, de Nijs SB, et al. Risk factors for frequent severe exacerbations in late-onset eosinophilic asthma. Am J Respir Crit Care Med 2015; 192: 899-902.

38 Green RM, Custovic A, Sanderson G, et al. Synergism between allergens and viruses and risk of hospita admission with asthma: case-control study. BMJ 2002; 324: 763.

39 Gonzalez-Barcala F-J, Calvo-Alvarez U, Garcia-Sanz M-T, et al. Characteristics and prognosis of near-fatal asthma exacerbations. Am J Med Sci 2015; 350: 98-102.

40 Jackson DJ, Sykes A, Mallia P, et al. Asthma exacerbations: origin, effect, and prevention. J Allergy Clin Immunol 2011; 128: 1165-1174.

41 Martinez-Moragón E, Plaza V, Serrano J, et al. Near-fatal asthma related to menstruation. J Allergy Clin Immunol 2004; 113: 242-244.

42 Kupczyk M, Haque S, Sterk PJ, et al. Detection of exacerbations in asthma based on electronic diary data: results from the 1-year prospective BIOAIR study. Thorax 2013; 68: 611-618.

43 Tattersfield AE, Postma DS, Barnes PJ, et al. Exacerbations of asthma: a descriptive study of 425 severe exacerbations. The FACET International Study Group. Am J Respir Crit Care Med 1999; 160: 594-599.

44 Romagnoli M, Caramori G, Braccioni F, et al. Near-fatal asthma phenotype in the ENFUMOSA Cohort. Clin Exp Allergy 2007; 37: 552-557.

45 Honkoop PJ, Simpson A, Bonini M, et al. MyAirCoach: the use of home-monitoring and mHealth systems to predict deterioration in asthma control and the occurrence of asthma exacerbations; study protocol of an observational study. BMJ Open 2017; 7: e013935.

46 Bateman ED, Buhl R, O’Byrne PM, et al. Development and validation of a novel risk score for asthma exacerbations: the risk score for exacerbations. J Allergy Clin Immunol 2015; 135: 1457-1464.e4.

47 Bateman ED, Reddel HK, Eriksson G, et al. Overall asthma control: the relationship between current control and future risk. J Allergy Clin Immunol 2010; 125: 600-608.

48 Jia CE, Zhang HP, Lv Y, et al. The Asthma Control Test and Asthma Control Questionnaire for assessing asthma control: systematic review and meta-analysis. J Allergy Clin Immunol 2013; 131: 695-703.

49 Sato R, Tomita K, Sano H, et al. The strategy for predicting future exacerbation of asthma using a combination of the Asthma Control Test and lung function test. J Asthma 2009; 46: 677-682.

50 Stern G, de Jongste J, van der Valk R, et al. Fluctuation phenotyping based on daily fraction of exhaled nitric oxide values in asthmatic children. J Allergy Clin Immunol 2011; 128: 293-300.

51 McFadden ER, Strauss L, Hejal R, et al. Comparison of two dosage regimens of albuterol in acute asthma. Am J Med 1998; 105: 12-17.

52 Turner MO, Noertjojo K, Vedal S, et al. Risk factors for near-fatal asthma. a case-control study in hospitalized patients with asthma. Am J Respir Crit Care Med 1998; 157: 1804-1809.

53 Loymans RJB, Honkoop PJ, Termeer EH, et al. Identifying patients at risk for severe exacerbations of asthma: development and external validation of a multivariable prediction model. Thorax 2016; 71: 838-846.

54 Denlinger LC, Phillips BR, Ramratnam S, et al. Inflammatory and comorbid features of patients with severe asthma and frequent exacerbations. Am J Respir Crit Care Med 2017; 195: 302-313.

55 Murray CS. study of modifiable risk factors for asthma exacerbations: virus infection and allergen exposure increase the risk of asthma hospital admissions in children. Thorax 2006; 61: 376-382.

56 Panico L, Stuart B, Bartley M, et al. Asthma trajectories in early childhood: identifying modifiable factors. PLoS One 2014; 9: e111922.

57 Smith LA, Bokhour B, Hohman KH, et al. Modifiable risk factors for suboptimal control and controller medication underuse among children with asthma. Pediatrics 2008; 122: 760-769.

58 Warman K, Silver EJ, Wood PR. Modifiable risk factors for asthma morbidity in Bronx versus other inner-city children. J Asthma 2009; 46: 995-1000.

59 Eggo RM, Scott JG, Galvani AP, et al. Respiratory virus transmission dynamics determine timing of asthma exacerbation peaks: evidence from a population-level model. Proc Natl Acad Sci 2016; 113: 2194-2199.

60 Jamieson KC, Warner SM, Leigh R, et al. Rhinovirus in the pathogenesis and clinical course of asthma. Chest 2015; 148: 1508-1516.

61 Clarke DL, Davis NHE, Majithiya JB, et al. Development of a mouse model mimicking key aspects of a viral asthma exacerbation. Clin Sci 2014; 126: 567-580

62 Gavala ML, Bertics PJ, Gern JE. Rhinoviruses, allergic inflammation, and asthma. Immunol Rev 2011; 242: 69-90.

63 Price DB, Rigazio A, Campbell JD, et al. Blood eosinophil count and prospective annual asthma disease burden: a UK cohort study. Lancet Respir Med 2015; 3: 849-858. 
Bleecker ER, FitzGerald JM, Chanez P, et al. Efficacy and safety of benralizumab for patients with severe asthma uncontrolled with high-dosage inhaled corticosteroids and long-acting $\beta 2$-agonists (SIROCCO): a randomised, multicentre, placebo-controlled phase 3 trial. Lancet 2016; 388: 2115-2127.

Pavord ID, Korn S, Howarth P, et al. Mepolizumab for severe eosinophilic asthma (DREAM): a multicentre, double-blind, placebo-controlled trial. Lancet 2012; 380: 651-659.

Nowak RM, Parker JM, Silverman RA, et al. A randomized trial of benralizumab, an antiinterleukin 5 receptor $\alpha$ monoclonal antibody, after acute asthma. Am J Emerg Med 2015; 33: 14-20.

Agusti A, Bel E, Thomas M, et al. Treatable traits: toward precision medicine of chronic airway diseases. Eur Respir J 2016; 47: 410-419.

Castro M, Corren J, Pavord ID, et al. Dupilumab efficacy and safety in moderate-to-severe uncontrolled asthma. N Engl J Med 2018; 378: 2486-2496.

Rabe KF, Nair P, Brusselle G, et al. Efficacy and safety of dupilumab in glucocorticoid-dependent severe asthma. N Engl J Med 2018; 378: 2475-2485.

Reddel HK, Bateman ED, Becker A, et al. A summary of the new GINA strategy: a roadmap to asthma control. Eur Respir J 2015; 46: 622-639.

Bønnelykke K, Sleiman P, Nielsen K, et al. A genome-wide association study identifies CDHR3 as a susceptibility locus for early childhood asthma with severe exacerbations. Nat Genet 2014; 46: 51-55.

McGeachie MJ, Wu AC, Tse SM, et al. CTNNA3 and SEMA3D: Promising loci for asthma exacerbation identified through multiple genome-wide association studies. J Allergy Clin Immunol 2015; 136: 1503-1510.

Grotenboer NS, Ketelaar ME, Koppelman GH, et al. Decoding asthma: translating genetic variation in IL33 and IL1RL1 into disease pathophysiology. J Allergy Clin Immunol 2013; 131: 856-865.

Ober C, Yao T-C. The genetics of asthma and allergic disease: a 21st century perspective. Immunol Rev 2011; 242: $10-30$.

Torgerson DG, Ampleford EJ, Chiu GY, et al. Meta-analysis of genome-wide association studies of asthma in ethnically diverse North American populations. Nat Genet 2011; 43: 887-892.

Schuijs MJ, Willart MA, Vergote K, et al. Farm dust and endotoxin protect against allergy through A20 induction in lung epithelial cells. Science 2015; 349: 1106-1110.

Meyers DA, Bleecker ER, Holloway JW, et al. Asthma genetics and personalised medicine. Lancet Respir Med 2014; 2: 405-415.

Wan YI, Shrine NRG, Soler Artigas M, et al. Genome-wide association study to identify genetic determinants of severe asthma. Thorax 2012; 67: 762-768.

Moffatt MF, Gut IG, Demenais F, et al. A large-scale, consortium-based genomewide association study of asthma. N Engl J Med 2010; 363: 1211-1221.

Wenzel SE, Balzar S, Ampleford E, et al. IL4R alpha mutations are associated with asthma exacerbations and mast cell/IgE expression. Am J Respir Crit Care Med 2007; 175: 570-576.

Slager RE, Otulana BA, Hawkins GA, et al. IL-4 receptor polymorphisms predict reduction in asthma exacerbations during response to an anti-IL-4 receptor $\alpha$ antagonist. J Allergy Clin Immunol 2012; 130: 516-522.

Dahlin A, Denny J, Roden DM, et al. CMTR1 is associated with increased asthma exacerbations in patients taking inhaled corticosteroids. Immun Inflamm Dis 2015; 3: 350-359.

Suissa S, Ernst P, Benayoun S, et al. Low-dose inhaled corticosteroids and the prevention of death from asthma. N Engl J Med 2000; 343: 332-336.

Levy ML. The national review of asthma deaths: what did we learn and what needs to change? Breathe (Sheff) 2015; 11: 14-24.

Lötvall J, Akdis CA, Bacharier LB, et al. Asthma endotypes: a new approach to classification of disease entities within the asthma syndrome. J Allergy Clin Immunol 2011; 127: 355-360.

Moore WC, Meyers DA, Wenzel SE, et al. Identification of asthma phenotypes using cluster analysis in the Severe Asthma Research Program. Am J Respir Crit Care Med 2010; 181: 315-323. sputum omics. J Allergy Clin Immunol 2017; 139: 1797-1807.

Longo C, Bartlett G, Schuster T, et al. The obese-asthma phenotype in children: an exacerbating situation? J Allergy Clin Immunol 2018; 141: 1239-1249.e4.

Morjaria JB, Rigby AS, Morice AH. Asthma phenotypes: do cough and wheeze predict exacerbations in persistent asthma? Eur Respir J 2017; 50: 1701366.

Ghebre MA, Pang PH, Diver S, et al. Biological exacerbation clusters demonstrate asthma and chronic obstructive pulmonary disease overlap with distinct mediator and microbiome profiles. J Allergy Clin Immunol 2018; 141: 2027-2036.e12.

Fricker M, Gibson PG, Powell H, et al. A sputum 6-gene signature predicts future exacerbations of poorly controlled asthma. J Allergy Clin Immunol 2019; 144: 51-60.e11.

Rothenberg ME, Hogan SP. The eosinophil. Annu Rev Immunol 2006; 24: 147-174.

Doshi V, Shenoy S, Ganesh A, et al. Near fatal asthma in an inner city population. Am J Ther 2016; 23 : e1375-e1380.

Al-Dorzi HM, Al-Shammary HA, Al-Shareef SY, et al. Risk factors, management and outcomes of patients admitted with near fatal asthma to a tertiary care hospital in Riyadh. Ann Thorac Med 2014; 9: 33-38.

Newth CJL, Meert KL, Clark AE, et al. Fatal and near-fatal asthma in children: the critical care perspective. J Pediatr 2012; 161: 214-221.

Becker JM, Rogers J, Rossini G, et al. Asthma deaths during sports: report of a 7-year experience. J Allergy Clin Immunol 2004; 113: 264-267.

Sunyer J, Basagaña X, Belmonte J, et al. Effect of nitrogen dioxide and ozone on the risk of dying in patients with severe asthma. Thorax 2002; 57: 687-693.

Serrano-Pariente J, Rodrigo G, Fiz JA, et al. Identification and characterization of near-fatal asthma phenotypes by cluster analysis. Allergy 2015; 70: 1139-1147.

Dhuper S, Maggiore D, Chung V, et al. Profile of near-fatal asthma in an inner-city hospital. Chest 2003; 124: $1880-1884$. 
Schatz M, Hsu J-WY, Zeiger RS, et al. Phenotypes determined by cluster analysis in severe or difficult-to-treat asthma. J Allergy Clin Immunol 2014; 133: 1549-1556.

D'Amato G, Liccardi G, D'Amato M, et al. Environmental risk factors and allergic bronchial asthma. Clin Exp Allergy 2005; 35: 1113-1124.

Boulet L-P, Vervloet D, Magar Y, et al. Adherence: the goal to control asthma. Clin Chest Med 2012; 33: 405-417.

Williams LK, Peterson EL, Wells K, et al. Quantifying the proportion of severe asthma exacerbations attributable to inhaled corticosteroid nonadherence. J Allergy Clin Immunol 2011; 128: 1185-1191.

Hasegawa K, Brenner BE, Clark S, et al. Emergency department visits for acute asthma by adults who ran out of their inhaled medications. Allergy Asthma Proc 2014; 35: 268-268.

Usmani OS, Lavorini F, Marshall J, et al. Critical inhaler errors in asthma and COPD: a systematic review of impact on health outcomes. Respir Res 2018; 19: 10.

Björnsdóttir US, Gizurarson S, Sabale U. Potential negative consequences of non-consented switch of inhaled medications and devices in asthma patients. Int J Clin Pract 2013; 67: 904-910.

Serrano J. Alexithymia: a relevant psychological variable in near-fatal asthma. Eur Respir J 2006; 28: 296-302.

Halimi L, Pry R, Pithon G, et al. Severe asthma and adherence to peak flow monitoring: longitudinal assessment of psychological aspects. J Psychosom Res 2010; 69: 331-340.

Singh AK. Sex differences among adults presenting to the emergency department with acute asthma. Arch Intern Med 1999; 159: 1237-1243.

Zein JG, Erzurum SC. Asthma is different in women. Curr Allergy Asthma Rep 2015; 15: 28

Chandra D, Clark S, Camargo CA. Race/ethnicity differences in the inpatient management of acute asthma in the United States. Chest 2009; 135: 1527-1534.

El-Ekiaby A, Brianas L, Skowronski ME, et al. Impact of race on the severity of acute episodes of asthma and adrenergic responsiveness. Am J Respir Crit Care Med 2006; 174: 508-513.

De Simoni A, Horne R, Fleming L, et al. What do adolescents with asthma really think about adherence to inhalers? Insights from a qualitative analysis of a UK online forum. BMJ Open 2017; 7: e015245.

Del Giacco SR, Cappai A, Gambula L, et al. The asthma-anxiety connection. Respir Med 2016; 120: 44-53.

Ciprandi G, Schiavetti I, Rindone E, et al. The impact of anxiety and depression on outpatients with asthma. Ann Allergy Asthma Immunol 2015; 115: 408-414. 5: $376-378$ Cea-Calvo L, Carmona L, Calvo-Alén J. The challenge of assessing adherence to subcutaneous biological drugs in immune-mediated inflammatory diseases. Adv Ther 2017; 34: 2173-2176.

Poureslami I, Shum J, Lester RT, et al. A pilot randomized controlled trial on the impact of text messaging check-ins and a web-based asthma action plan versus a written action plan on asthma exacerbations. J Asthma 2018: 1-13.

Chan AHY, Stewart AW, Harrison J, et al. The effect of an electronic monitoring device with audiovisual reminder function on adherence to inhaled corticosteroids and school attendance in children with asthma: a randomised controlled trial. Lancet Respir Med 2015; 3: 210-219.

Foster JM, Usherwood T, Smith L, et al. Inhaler reminders improve adherence with controller treatment in primary care patients with asthma. J Allergy Clin Immunol 2014; 134: 1260-1268.

James KM, Peebles RS, Hartert TV. Response to infections in patients with asthma and atopic disease: an epiphenomenon or reflection of host susceptibility? J Allergy Clin Immunol 2012; 130: 343-351.

Jackson DJ, Gangnon RE, Evans MD, et al. Wheezing rhinovirus illnesses in early life predict asthma development in high-risk children. Am J Respir Crit Care Med 2008; 178: 667-672.

Kusel MMH, de Klerk NH, Kebadze T, et al. Early-life respiratory viral infections, atopic sensitization, and risk of subsequent development of persistent asthma. J Allergy Clin Immunol 2007; 119: 1105-1110. 2006; 91: 405-409.

Teach SJ, Gill MA, Togias A, et al. Preseasonal treatment with either omalizumab or an inhaled corticosteroid boost to prevent fall asthma exacerbations. J Allergy Clin Immunol 2015; 136: 1476-1485.

Corne JM, Marshall C, Smith S, et al. Frequency, severity, and duration of rhinovirus infections in asthmatic and non-asthmatic individuals: a longitudinal cohort study. Lancet 2002; 359: 831-834.

Wark PAB, Johnston SL, Bucchieri F, et al. Asthmatic bronchial epithelial cells have a deficient innate immune response to infection with rhinovirus. J Exp Med 2005; 201: 937-947.

Baraldo S, Contoli M, Bazzan E, et al. Deficient antiviral immune responses in childhood: distinct roles of atopy and asthma. J Allergy Clin Immunol 2012; 130: 1307-1314.

Bochkov YA, Watters K, Ashraf S, et al. Cadherin-related family member 3, a childhood asthma susceptibility gene product, mediates rhinovirus C binding and replication. Proc Natl Acad Sci USA 2015; 112: 5485-5490.

Ducharme FM, Zemek R, Chauhan BF, et al. Factors associated with failure of emergency department management in children with acute moderate or severe asthma: a prospective, multicentre, cohort study. Lancet Respir Med 2016; 4: 990-998.

Contoli M, Message SD, Laza-Stanca V, et al. Role of deficient type III interferon-lambda production in asthma exacerbations. Nat Med 2006; 12: 1023-1026.

Glanville N, Johnston SL. Challenges in developing a cross-serotype rhinovirus vaccine. Curr Opin Virol 2015; 11: 83-88.

Djukanović R, Harrison T, Johnston SL, et al. The effect of inhaled IFN- $\beta$ on worsening of asthma symptoms caused by viral infections. A randomized trial. Am J Respir Crit Care Med 2014; 190: 145-154.

Henneberger PK, Mirabelli MC, Kogevinas M, et al. The occupational contribution to severe exacerbation of asthma. Eur Respir J 2010; 36: 743-750.

Jie Y, Isa ZM, Jie X, et al. Urban vs. Rural Factors That Affect Adult Asthma. In: Whitacre DM, ed. Reviews of Environmental Contamination and Toxicology Volume 226. New York, Springer New York, 2013; pp. 33-63.

Spitzer WO, Suissa S, Ernst P, et al. The use of beta-agonists and the risk of death and near death from asthma. N Engl J Med 1992; 326: 501-506. 


\section{a novel mech} 1999; 353: 364-369.

145 Castillo JR, Peters SP, Busse WW. Asthma exacerbations: pathogenesis, prevention, and treatment. J Allergy Clin Immunol Pract 2017; 5: 918-927.

146 Shim CS, Williams MH. Evaluation of the severity of asthma: patients versus physicians. Am J Med 1980; 68: $11-13$.

147 Carruthers DM, Harrison BD. Arterial blood gas analysis or oxygen saturation in the assessment of acute asthma? Thorax 1995; 50: 186-188.

148 Nowak RM, Tomlanovich MC, Sarkar DD, et al. Arterial blood gases and pulmonary function testing in acute bronchial asthma. Predicting patient outcomes. JAMA 1983; 249: 2043-2046.

149 White CS, Cole RP, Lubetsky HW, et al. Acute asthma. Admission chest radiography in hospitalized adult patients. Chest 1991; 100: 14-16.

150 Perrin K, Wijesinghe M, Healy B, et al. Randomised controlled trial of high concentration versus titrated oxygen therapy in severe exacerbations of asthma. Thorax 2011; 66: 937-941.

151 Rodrigo GJ. Oxygen treatment for acute severe asthma. Oxygen saturation may help identify patients in need of intensive management. BMJ 2001; 323: 1069.

152 Rodrigo GJ, Rodriquez Verde M, Peregalli V, et al. Effects of short-term $28 \%$ and $100 \%$ oxygen on PaCO 2 and peak expiratory flow rate in acute asthma: a randomized trial. Chest 2003 ; 124: 1312-1317.

153 Cates CJ, Welsh EJ, Rowe BH. Holding chambers (spacers) versus nebulisers for beta-agonist treatment of acute asthma. Cochrane Database Syst Rev 2013: CD000052.

154 Newman KB, Milne S, Hamilton C, et al. A comparison of albuterol administered by metered-dose inhaler and spacer with albuterol by nebulizer in adults presenting to an urban emergency department with acute asthma. Chest 2002; 121: 1036-1041.

155 Camargo CA, Spooner CH, Rowe BH. Continuous versus intermittent beta-agonists in the treatment of acute asthma. Cochrane Database Syst Rev 2003: CD001115.

156 Rodrigo GJ, Rodrigo C. Continuous vs intermittent beta-agonists in the treatment of acute adult asthma: a systematic review with meta-analysis. Chest 2002; 122: 160-165.

157 Shrestha M, Bidadi K, Gourlay S, et al. Continuous vs intermittent albuterol, at high and low doses, in the treatment of severe acute asthma in adults. Chest 1996; 110: 42-47.

158 Travers AH, Milan SJ, Jones AP, et al. Addition of intravenous beta(2)-agonists to inhaled beta(2)-agonists for acute asthma. Cochrane Database Syst Rev 2012; 12: CD010179.

159 Griffiths B, Ducharme FM. Combined inhaled anticholinergics and short-acting beta2-agonists for initial treatment of acute asthma in children. Cochrane Database Syst Rev 2013: CD000060.

160 Rodrigo G, Rodrigo C, Burschtin O. A meta-analysis of the effects of ipratropium bromide in adults with acute asthma. Am J Med 1999; 107: 363-370.

161 Stoodley RG, Aaron SD, Dales RE. The role of ipratropium bromide in the emergency management of acute asthma exacerbation: a metaanalysis of randomized clinical trials. Ann Emerg Med 1999; 34: 8-18.

162 Manser R, Reid D, Abramson M. Corticosteroids for acute severe asthma in hospitalised patients. Cochrane Database Syst Rev 2001: CD001740.

163 Rowe BH, Spooner CH, Ducharme FM, et al. Corticosteroids for preventing relapse following acute exacerbations of asthma. Cochrane Database Syst Rev 2007: CD000195.

164 Rowe BH, Spooner C, Ducharme FM, et al. Early emergency department treatment of acute asthma with systemic corticosteroids. Cochrane Database Syst Rev 2001: CD002178.

165 Marquette CH, Stach B, Cardot E, et al. High-dose and low-dose systemic corticosteroids are equally efficient in acute severe asthma. Eur Respir J 1995; 8: 22-27.

166 Harrison BD, Stokes TC, Hart GJ, et al. Need for intravenous hydrocortisone in addition to oral prednisolone in patients admitted to hospital with severe asthma without ventilatory failure. Lancet 1986; 1: 181-184.

167 Ratto D, Alfaro C, Sipsey J, et al. Are intravenous corticosteroids required in status asthmaticus? JAMA 1988; 260: 527-529.

168 Jones AM, Munavvar M, Vail A, et al. Prospective, placebo-controlled trial of 5 vs 10 days of oral prednisolone in acute adult asthma. Respir Med 2002; 96: 950-954.

169 O'Driscoll BR, Kalra S, Wilson M, et al. Double-blind trial of steroid tapering in acute asthma. Lancet 1993; 341: 324-327.

170 Edmonds ML, Milan SJ, Camargo CA, et al. Early use of inhaled corticosteroids in the emergency department treatment of acute asthma. Cochrane Database Syst Rev 2012; 12: CD002308.

171 Kew KM, Kirtchuk L, Michell CI. Intravenous magnesium sulfate for treating adults with acute asthma in the emergency department. Cochrane Database Syst Rev 2014: CD010909.

172 Rowe $\mathrm{BH}$, Bretzlaff JA, Bourdon $\mathrm{C}$, et al. Intravenous magnesium sulfate treatment for acute asthma in the emergency department: a systematic review of the literature. Ann Emerg Med 2000; 36: 181-190. 
173 National Asthma Education and Prevention Program. Expert Panel Report 3 (EPR-3): Guidelines for the Diagnosis and Management of Asthma-Summary Report 2007. J Allergy Clin Immunol 2007; 120: S94-S138.

174 Charriot J, Volpato M, Sueh C, et al. Asthma: treatment and prevention of pulmonary exacerbations. In: Burgel P-R, Contoli M, López-Campos JL, eds. Acute Exacerbations of Pulmonary Diseases (ERS Monograph). Sheffield, European Respiratory Society, 2017; pp. 129-146.

175 França-Pinto A, Mendes FAR, de Carvalho-Pinto RM, et al. Aerobic training decreases bronchial hyperresponsiveness and systemic inflammation in patients with moderate or severe asthma: a randomised controlled trial. Thorax 2015; 70: 732-739.

176 National Heart, Lung, and Blood Institute (NHLBI). Guidelines for the Diagnosis and Management of Asthma (EPR-3). Bethesda, National Heart, Lung, and Blood Institute (NHLBI), 2007. Available from www.nhlbi.nih.gov/ health-topics/guidelines-for-diagnosis-management-of-asthma

177 British Thoracic Society. BTS/SIGN British Guideline on the Management of Asthma. London, British Thoracic Society, 2016. Available from www.brit-thoracic.org.uk/standards-of-care/guidelines/btssign-british-guideline-onthe-management-of-asthma/

178 McKeever T, Mortimer K, Wilson A, et al. Quadrupling inhaled glucocorticoid dose to abort asthma exacerbations. N Engl J Med 2018; 378: 902-910.

179 Volmer T, Effenberger T, Trautner C, et al. Consequences of long-term oral corticosteroid therapy and its side-effects in severe asthma in adults: a focused review of the impact data in the literature. Eur Respir J 2018; 52: 1800703.

180 Sweeney J, Brightling CE, Menzies-Gow A, et al. Clinical management and outcome of refractory asthma in the UK from the British Thoracic Society Difficult Asthma Registry. Thorax 2012; 67: 754-756.

181 Mancinelli L, Navarro L, Sharma OP. Intramuscular high-dose triamcinolone acetonide in the treatment of severe chronic asthma. West J Med 1997; 167: 322-329.

182 Pavord ID, Brightling CE, Woltmann G, et al. Non-eosinophilic corticosteroid unresponsive asthma. Lancet 1999; 353: 2213-2214.

183 Brightling CE, Monteiro W, Ward R, et al. Sputum eosinophilia and short-term response to prednisolone in chronic obstructive pulmonary disease: a randomised controlled trial. Lancet 2000; 356: 1480-1485.

184 Pratter MR, Brightling CE, Boulet LP, et al. An empiric integrative approach to the management of cough: ACCP evidence-based clinical practice guidelines. Chest 2006; 129: 222S-231S.

185 Chlumský J, Striz I, Terl M, et al. Strategy aimed at reduction of sputum eosinophils decreases exacerbation rate in patients with asthma. J Int Med Res 2006; 34: 129-139.

186 O'Byrne PM, FitzGerald JM, Bateman ED, et al. Inhaled combined budesonide-formoterol as needed in mild asthma. N Engl J Med 2018; 378: 1865-1876.

187 Bateman ED, Reddel HK, O’Byrne PM, et al. As-needed budesonide-formoterol versus maintenance budesonide in mild asthma. N Engl J Med 2018; 378: 1877-1887.

188 Beasley R, Holliday M, Reddel HK, et al. Controlled trial of budesonide-formoterol as needed for mild asthma. $N$ Engl J Med 2019; 380: 2020-2030.

189 National Association for Medical Direction of Respiratory Care (NAMDRC). FDA Removes Boxed Warning from Long-Acting Beta Agonists (LABAs) and Inhaled Corticosteroids (ICS) www.namdrc.org/posts/ fda-removes-boxed-warning-long-acting-beta-agonists-labas-and-inhaled-corticosteroids-ics Date last updated: 04 Jan 2018. Date last accessed: 19 Oct 2018.

190 Kerstjens HAM, Engel M, Dahl R, et al. Tiotropium in asthma poorly controlled with standard combination therapy. N Engl J Med 2012; 367: 1198-1207.

191 Anderson DE, Kew KM, Boyter AC. Long-acting muscarinic antagonists (LAMA) added to inhaled corticosteroids (ICS) versus the same dose of ICS alone for adults with asthma. Cochrane Database Syst Rev 2015: CD011397.

192 Miligkos M, Bannuru RR, Alkofide H, et al. Leukotriene-receptor antagonists versus placebo in the treatment of asthma in adults and adolescents: a systematic review and meta-analysis. Ann Intern Med 2015; 163: 756-767.

193 Nie H, Zhang G, Liu M, et al. Efficacy of theophylline plus salmeterol/fluticasone propionate combination therapy in patients with asthma. Respir Med 2013; 107: 347-354.

194 Gibson PG, Yang IA, Upham JW, et al. Effect of azithromycin on asthma exacerbations and quality of life in adults with persistent uncontrolled asthma (AMAZES): a randomised, double-blind, placebo-controlled trial. Lancet 2017; 390: 659-668.

195 Brusselle GG, Vanderstichele C, Jordens P, et al. Azithromycin for prevention of exacerbations in severe asthma (AZISAST): a multicentre randomised double-blind placebo-controlled trial. Thorax 2013; 68: 322-329.

196 Agbetile J, Bourne M, Fairs A, et al. Effectiveness of voriconazole in the treatment of Aspergillus fumigatus-associated asthma (EVITA3 study). J Allergy Clin Immunol 2014; 134: 33-39.

197 Evans DJ, Cullinan P, Geddes DM. Cyclosporin as an oral corticosteroid sparing agent in stable asthma. Cochrane Database Syst Rev 2001: CD002993.

198 Davies H, Olson L, Gibson P. Methotrexate as a steroid sparing agent for asthma in adults. Cochrane Database Syst Rev 2000: CD000391.

199 Woodcock A, Forster L, Matthews E, et al. Control of exposure to mite allergen and allergen-impermeable bed covers for adults with asthma. N Engl J Med 2003; 349: 225-236.

200 Normansell R, Kew KM, Bridgman A-L. Sublingual immunotherapy for asthma. Cochrane Database Syst Rev 2015: CD011293.

201 Rajaram J SoMOSA: Study of mechanisms of action of omalizumab in severe asthma. ISRCTN registry: ISRCTN15124178. https://doi.org/10.1186/ISRCTN15124178 Date last accessed: 21 Sept 2018.

202 Chauhan AJ, Balls L. Laminar Airflow in Severe Asthma for Exacerbation Reduction - 48 Month Follow-up. ClinicalTrials.gov registry: NCT02813811. https://clinicaltrials.gov/ct2/show/NCT02813811 Date last updated: 27 July 2016. Date last accessed: 21 Sept 2018.

203 Normansell R, Walker S, Milan SJ, et al. Omalizumab for asthma in adults and children. Cochrane Database Syst Rev 2014: CD003559.

204 Haldar P, Brightling CE, Hargadon B, et al. Mepolizumab and exacerbations of refractory eosinophilic asthma. N Engl J Med 2009; 360: 973-984. 
Chupp GL, Bradford ES, Albers FC, et al. Efficacy of mepolizumab add-on therapy on health-related quality of life and markers of asthma control in severe eosinophilic asthma (MUSCA): a randomised, double-blind, placebo-controlled, parallel-group, multicentre, phase 3b trial. Lancet Respir Med 2017; 5: 390-400.

206 Bel EH, Wenzel SE, Thompson PJ, et al. Oral glucocorticoid-sparing effect of mepolizumab in eosinophilic asthma. N Engl J Med 2014; 371: 1189-1197.

207 Ortega HG, Yancey SW, Mayer B, et al. Severe eosinophilic asthma treated with mepolizumab stratified by baseline eosinophil thresholds: a secondary analysis of the DREAM and MENSA studies. Lancet Respir Med 2016; 4: 549-556.

208 Haldar P, Brightling CE, Singapuri A, et al. Outcomes after cessation of mepolizumab therapy in severe eosinophilic asthma: a 12-month follow-up analysis. J Allergy Clin Immunol 2014; 133: 921-923.

209 Lugogo N, Domingo C, Chanez P, et al. Long-term efficacy and safety of mepolizumab in patients with severe eosinophilic asthma: a multi-center, open-label, phase iiib study. Clin Ther 2016; 38: 2058-2070.

210 Castro M, Zangrilli J, Wechsler ME, et al. Reslizumab for inadequately controlled asthma with elevated blood eosinophil counts: results from two multicentre, parallel, double-blind, randomised, placebo-controlled, phase 3 trials. Lancet Respir Med 2015; 3: 355-366.

211 Brusselle G, Canvin J, Weiss S, et al. Stratification of eosinophilic asthma patients treated with reslizumab and GINA Step 4 or 5 therapy. ERJ Open Res 2017; 3: 00004-2017.

212 FitzGerald JM, Bleecker ER, Nair P, et al. Benralizumab, an anti-interleukin-5 receptor $\alpha$ monoclonal antibody, as add-on treatment for patients with severe, uncontrolled, eosinophilic asthma (CALIMA): a randomised, double-blind, placebo-controlled phase 3 trial. Lancet 2016; 388: 2128-2141.

213 Nair P, Wenzel S, Rabe KF, et al. Oral glucocorticoid-sparing effect of benralizumab in severe asthma. $N$ Engl $J$ Med 2017; 376: 2448-2458.

214 Goldman M, Hirsch I, Zangrilli JG, et al. The association between blood eosinophil count and benralizumab efficacy for patients with severe, uncontrolled asthma: subanalyses of the Phase III SIROCCO and CALIMA studies. Curr Med Res Opin 2017; 33: 1605-1613.

215 FitzGerald JM, Bleecker ER, Menzies-Gow A, et al. Predictors of enhanced response with benralizumab for patients with severe asthma: pooled analysis of the SIROCCO and CALIMA studies. Lancet Respir Med 2018; 6: 51-64.

216 Wechsler ME, Laviolette M, Rubin AS, et al. Bronchial thermoplasty: long-term safety and effectiveness in patients with severe persistent asthma. J Allergy Clin Immunol 2013; 132: 1295-1302.

217 Wenzel S, Ford L, Pearlman D, et al. Dupilumab in persistent asthma with elevated eosinophil levels. $N$ Engl Med 2013; 368: 2455-2466.

218 Wenzel S, Castro M, Corren J, et al. Dupilumab efficacy and safety in adults with uncontrolled persistent asthma despite use of medium-to-high-dose inhaled corticosteroids plus a long-acting $\beta 2$ agonist: a randomised double-blind placebo-controlled pivotal phase 2b dose-ranging trial. Lancet 2016; 388: 31-44.

219 Hanania NA, Korenblat P, Chapman KR, et al. Efficacy and safety of lebrikizumab in patients with uncontrolled asthma (LAVOLTA I and LAVOLTA II): replicate, phase 3, randomised, double-blind, placebo-controlled trials. Lancet Respir Med 2016; 4: 781-796.

220 Russell RJ, Chachi L, FitzGerald JM, et al. Effect of tralokinumab, an interleukin-13 neutralising monoclonal antibody, on eosinophilic airway inflammation in uncontrolled moderate-to-severe asthma (MESOS): a multicentre, double-blind, randomised, placebo-controlled phase 2 trial. Lancet Respir Med 2018; 6: 499-510.

221 Corren J, Parnes JR, Wang L, et al. Tezepelumab in adults with uncontrolled asthma. N Engl J Med 2017; 377: 936-946.

222 Gonem S, Berair R, Singapuri A, et al. Fevipiprant, a prostaglandin D2 receptor 2 antagonist, in patients with persistent eosinophilic asthma: a single-centre, randomised, double-blind, parallel-group, placebo-controlled trial. Lancet Respir Med 2016; 4: 699-707.

223 Efficacy and Safety Study of GSK3772847 in Subjects With Moderately Severe Asthma. ClinicalTrials.gov registry: NCT03207243. https:/clinicaltrials.gov/ct2/show/NCT03207243 Date last updated: 18 June 2019. Date last accessed: 21 Sept 2018.

224 Study to Assess the Efficacy and Safety of CJM112 in Patients With Inadequately Controlled Severe Asthma. ClinicalTrials.gov registry: NCT03299686. https:/clinicaltrials.gov/ct2/show/NCT03299686 Date last updated: 23 Jan 2019. Date last accessed: 21 Sept 2018. 